Research Article

\title{
Nutraceutical Potential of Five Mexican Brown Seaweeds
}

\author{
Ana Rocío Múzquiz de la Garza, ${ }^{1}$ Mireya Tapia-Salazar, ${ }^{1}$ Maribel Maldonado-Muñiz, ${ }^{1}$ \\ Julián de la Rosa-Millán, ${ }^{2}$ Janet Alejandra Gutiérrez-Uribe $\mathbb{B D}^{2},{ }^{2}$ Liliana Santos-Zea, ${ }^{2}$ \\ Bertha Alicia Barba-Dávila, ${ }^{2}$ Denis Ricque-Marie $\mathbb{1}^{1},{ }^{1}$ and Lucía Elizabeth Cruz-Suárez $\left(\mathbb{C}^{1}\right.$ \\ ${ }^{1}$ Universidad Autónoma de Nuevo León, Facultad de Ciencias Biológicas, Programa Maricultura, Ave. Universidad SN, \\ Cd. Universitaria F-67, San Nicolás de los Garza, Nuevo León 66455, Mexico \\ ${ }^{2}$ Tecnologico de Monterrey, Escuela de Ingeniería y Ciencias, Centro de Biotecnología-FEMSA, Av. Eugenio Garza Sada 2501 Sur, \\ Monterrey, Nuevo León 64849, Mexico
}

Correspondence should be addressed to Lucía Elizabeth Cruz-Suárez; lucia.cruzsr@uanl.edu.mx

Received 27 June 2019; Accepted 14 September 2019; Published 19 December 2019

Academic Editor: Abdelwahab Omri

Copyright (C) 2019 Ana Rocío Múzquiz de la Garza et al. This is an open access article distributed under the Creative Commons Attribution License, which permits unrestricted use, distribution, and reproduction in any medium, provided the original work is properly cited.

\begin{abstract}
In search of pharmaceutically active products to control type 2 diabetes, five brown seaweeds (Silvetia compressa, Cystoseira osmundacea, Ecklonia arborea, Pterygophora californica, and Egregia menziesii) from the Northwest Mexican Pacific coast were investigated. Proximate composition and total polyphenol content (TPC) as phloroglucinol equivalents (PGE) were determined for the five seaweed powders and their respective hydroethanolic $(1: 1)$ extracts. Extracts were screened for their radical scavenging activity (DPPH and ORAC) and glycosidase inhibitory activity. HPLC-DAD, HPLC-MS-TOF, and ATR-FT-IR methodologies were used to identify the most abundant phlorotannins and sulfated polysaccharides in the extracts. Hydroethanolic extracts contained minerals (17 to 59\% of the dry matter), proteins (4 to $9 \%$ ), ethanol-insoluble polysaccharides ( 5.4 to $53 \%$ ), nitrogen-free extract (NFE) (24.4 to $70.1 \%$ ), lipids (5 to $12 \%$ ), and TPC (2.6 to $47.7 \mathrm{~g}$ PGE per $100 \mathrm{~g}$ dry extract). S. compressa and E. arborea dry extracts presented the lowest ash content ( 26 and 17\%, respectively) and had some of the highest phenolic ( 47.7 and $15.2 \mathrm{~g}$ PGE per $100 \mathrm{~g}$ extract), NFE (57.3 and 70.1\%), and soluble polysaccharide (19.7 and 53\%) contents. S. compressa and E. arborea extracts had the highest antioxidant activity ( $\mathrm{IC}_{50} \mathrm{DPPH} 1.7$ and $3.7 \mathrm{mg} \mathrm{mL}^{-1}$; ORAC 0.817 and $0.801 \mathrm{mmol}$ Trolox equivalent/g extract) and the highest $\alpha$-amylase and $\alpha$-glucosidase inhibitory capacities ( $\mathrm{IC}_{50} 940$ and $1152 \mu \mathrm{g} \mathrm{mL} \mathrm{L}^{-1}$ against $\alpha$-amylase and 194 and $647 \mu \mathrm{g}$ $\mathrm{mL}^{-1}$ against $\alpha$-glucosidase). The most abundant phlorotannins identified in the extracts were phloretol, fucophloroethol, and two- and three-phloroglucinol unit (PGU) phlorotannins. Laminarin, fucoidan, and alginate were among the sulfated polysaccharides identified in the extracts. The bioactivities of $S$. compressa and E. arborea extracts were mainly related with their contents of three PGU phlorotannins and sulfated polysaccharides (e.g., fucoidan, laminarin, and alginate). These results suggest $S$. compressa and E. arborea are potential candidates for food products and nutraceutical and pharmaceutical preparations, and as additives for diabetes management.
\end{abstract}

\section{Introduction}

Globally, there are approximately 350 million people currently suffering from diabetes (http://www.who.int/ mediacentre/factsheets/fs $312 / \mathrm{en} /$ ). This number could potentially double by 2030 , which would make diabetes the seventh most prevalent cause of death worldwide [1]. Ninety percent of diabetes cases are type 2 diabetes mellitus, a complex disorder characterized by hyperglycemia and associated with high oxidative stress caused by the production of reactive oxygen species (ROS) [2]. Dietary starch degradation by glycosidases is the major source of glucose in the blood [3, 4]. Dietary polysaccharides are hydrolyzed by $\alpha$-amylase to oligosaccharides and disaccharides, which are further hydrolyzed to monosaccharides by $\alpha$-glucosidase (a membrane-bound intestinal enzyme that aids glucose liberation by acting as a catalyst in the hydrolysis of the $\alpha$-glycosidic bond found in oligosaccharides). Liberated glucose is absorbed from the intestine and contributes to postprandial hyperglycemia. Glycosidase inhibitors prevent 
or delay the hydrolysis or absorption of carbohydrates and reduce postprandial hyperglycemia, making such inhibitors useful in the management of type 2 diabetes [3,5]. Thus, antidiabetic therapies that limit the postprandial increase of blood glucose levels after a mixed carbohydrate diet, such as the use of glycosidase inhibitors, are particularly relevant in diabetes prevention and control $[6,7]$. Certain synthetic antidiabetic drugs that act by inhibiting $\alpha$-amylase and $\alpha$-glucosidase activity (e.g., acarbose, miglitol, and voglibose) are currently available, but they are associated with undesirable side effects, such as liver toxicity and adverse gastrointestinal symptoms [6, 8, 9]. Such adverse effects might be caused by the excessive inhibition of pancreatic $\alpha$-amylase, resulting in abnormal bacterial fermentation of undigested carbohydrates in the colon [9]. Lower inhibitory effect against $\alpha$-amylase activity and stronger inhibition activity against $\alpha$-glucosidase can be an ideal approach for managing hyperglycemia with minimal side effects [9]. Thus, there is a substantial need for natural $\alpha$-amylase and $\alpha$-glucosidase inhibitors that have no adverse or unwanted secondary effects $[6,7]$. A number of studies suggest that marine compounds may be convenient alternatives [8].

Seaweeds are rich in dietary fibre, polyphenolic compounds, unsaturated fatty acids, and minerals, among other compounds, many of which can be beneficial to human health, including in managing diabetes [10-13]. In fact, dietary consumption of seaweed $s$ was associated with a low incidence of diabetes in Korean men [14]. Particularly, numerous brown seaweed crude extracts (acetonic, aqueous, methanolic, and ethanolic) have shown to possess antioxidant $[15,16]$ and antidiabetic (e.g., $\alpha$-amylase and $\alpha$-glucosidase inhibition) activities [14, 17-19]. These activities are related to the presence of phenolic compounds, phlorotannins, pigments, tocopherols, polysaccharides, fatty acids, and peptides in the seaweed extracts [15, 20-28]. The main compounds reported as potent $\alpha$-amylase and $\alpha$-glucosidase inhibitors are as follows: phloroglucinol derivatives such as dieckol, 8, $8^{\prime}$-bieckol, phlorofucofuroeckol, fucophloroethol, and phlorotannins with low PGU $[23,25,29-31]$, fucoidan $[3,32,33]$, and oleic, linoleic, and eicosapentaenoic acids [24].

On the other hand, the major compounds contributing to overall antioxidant activity in seaweed are phenolic compounds and polysaccharides, the latter alone or associated with other components such as polyphenols, amino acid, protein, lipids, and nucleic acids residues, and sometimes polysaccharide conjugates [28, 34]. Hence, TPC and polysaccharides, in combination with in vitro antioxidant assays, are typically used to screen for seaweed antioxidant activity [34-36]. Previous studies have found a positive correlation between high TPC content and high radicalscavenging capacity for seaweed extracts [34, 35, 37]. Powerful antioxidant bioactivity was observed in dieckol (A), 6-6' -bieckol (B), and fucodiphlorethol G (C) separated and refined from Ecklonia cava, an edible marine alga collected at Jeju Island [38]. Sulfated polysaccharides also possess excellent in vitro antioxidant activity, including both radical-scavenging capacity and metal chelating ability [34, 39-41]. Therefore, substantial evidence exists to support the claim that seaweed extracts and their fractions could act as functional ingredients in foods used to control hyperglycemia [19, 27].

The coastline of Baja California, Mexico, is an abundant source of seaweeds with a broad diversity of species, some of which have been under commercial exploitation since the 1960s (e.g., Macrocystis pyrifera, Gelidium robustum, Chondracanthus canaliculatus, and Gracilariopsis lemaneiformis) to obtain alginate, agar, and carrageenan [42, 43]. In contrast, other commercially available edible brown seaweed species, such as Silvetia compressa (J. Agardh) (De Toni 1985), Cystoseira osmundacea (Turner) (C. Agardh 1820), Ecklonia arborea (Areschoug 1876), Pterygophora californica (Ruprecht, 1852), and Egregia menziesii (Turner) (Areschoug 1876), are incipiently being used as supplements for human and animal consumption, as well as in the elaboration of cosmetic products (https://www.bajakelp.net).

Although proximal composition, polyphenol content, and DPPH antioxidant activity have been previously reported for Ecklonia arborea (formerly Eisenia arborea) $[15,44-46]$, this information is incomplete or unavailable for S. compressa [46-48], E. menziesii [47], C. osmundacea, and $P$. californica from the Baja California coast. Neither the antidiabetic potential of these five seaweeds ( $\alpha$-amylase and $\alpha$-glucosidase inhibition activities) nor the chemical composition of their hydroethanolic extracts has been previously reported. This study seeks to screen the antioxidant and glycosidases inhibiting potential of hydroethanolic extracts from these five brown seaweeds, as well as to identify the probable active compounds: phlorotannins (using HPLCDAD and HPLC-MS-TOF methodologies) and sulfated polysaccharides (using ATR/FT-IR methodologies). Through this process, this study hopes to identify a potential commercial value for these five macroalgae native to Mexico's Baja California coast and to find candidates for the development of pharmaceutically active products that can control type 2 diabetes.

\section{Materials and Methods}

2.1. Chemicals and Reagents. Potato soluble starch (S-2360), $\alpha$-amylase from porcine pancreas (A-3176, $5 \mathrm{MU}$ ), acarbose (A-8980), rat intestinal acetone powders (I-1360), 4-nitrophenyl- $\alpha$-D-glucopyranoside (N-1377), Folin-Ciocalteu reagent (F-9252), sodium carbonate $\left(\mathrm{Na}_{2} \mathrm{CO}_{3}\right)$ (S-2127), phloroglucinol (P-3502), gallic acid (G-7384), 2,2-diphenyl-1picrylhydrazyl (DPPH) (D-9132), 3,5-dinitro-2-hydroxybenzoic acid (DNS) (D-0550), HEPES (4-(2-hydroxyethyl)-1piperazine ethanesulphonic acid) buffer solution (H3375), fucoidan from $F$. vesiculosus (F8190), laminarin from L digitate (L9634), sodium alginate from brown algae (w201502), fluorescein (F6377), and 2,2'-azobis (2-methylpropionamidine) dihydrochloride (AAPH, 4409914) were purchased from Sigma Aldrich Co. (St. Louis, MO, USA). Ethanol (absolute) was obtained from Desarrollo de Especialidades Químicas SA de CV (Monterrey, NL, Mexico). Distilled water was purchased from Garvy SA de CV (Monterrey, NL, Mexico); HPLC-grade water (4218-03) was obtained from J. T. Baker Co. (Center Valley, PA, USA). Formic 
acid 88\% (A11-8P) and HPLC-grade methanol (A452-4) were purchased from Fisher Scientific Co. (Pittsburgh, PA, USA). EDTA (502-092) was purchased from LECO Co. (St. Joseph, MI, USA).

2.2. Seaweeds. Five edible dehydrated seaweed samples were obtained from BajaKelp (https://www.bajakelp.net) in Ensenada, Baja California, Mexico. Samples of S. compressa (formerly Pelvetia compressa), C. osmundacea, E. arborea, $P$. californica, and E. menziesii were collected from December 2014 to January 2015 at La Escalera, Baja California Peninsula, Mexico ( $\left.31^{\circ} 30^{\prime} 59.1^{\prime \prime} \mathrm{N}-116^{\circ} 38^{\prime} 51.1^{\prime \prime} \mathrm{W}\right)$. Seaweed fronds were washed with seawater to remove sand and epiphytes, drained on clotheslines, and sun-dried inside a greenhouse in Ensenada, Baja California. Samples were ground at our lab in Monterrey, Nuevo León (Pulvex 200, CDMX, MEX), with a $500 \mu \mathrm{m}$ sieve and vacuum-packed until use. Identity of all five seaweed species was confirmed using taxonomic keys [49].

2.3. Proximal Composition of Seaweeds. Moisture and ash content were determined using 930.15 and 942.05 AOAC [50] procedures, respectively. Crude protein $(\mathrm{Nx6.25)}$ was quantified by AOAC 930.03 method using a nitrogen analyzer (Truspec CHN, Leco Corporation, St. Joseph, MI, USA). Crude lipid was determined using the Bligh and Dyer method, following the methodology described by Li et al.
[51]. Nitrogen-free extract (NFE) or carbohydrate value was estimated from the difference between dry weight (100) and the sum of total lipids, protein, and ash (minerals). Data were expressed as \% of seaweed dry matter (DM).

2.4. Preparation of Hydroethanolic Extracts. For phenolic compound extraction, we used the methodology described by Xi et al. [52]. For this, $10 \mathrm{~g}$ of seaweed powder and $200 \mathrm{~mL}$ aqueous ethanol $50 \%$ were mixed in a $250 \mathrm{~mL}$ Erlenmeyer flask and sonicated (Ultrasonic cleaner 50HT, VWR International, West Chester, PA, USA) for $30 \mathrm{~min}$. Samples were then incubated at $70^{\circ} \mathrm{C}$ with constant agitation at $100 \mathrm{rpm}$ (Shak-R-bath, Lab-line, Melrose Park, IL, USA) for $2 \mathrm{~h}$. Subsequently, samples were cooled down to room temperature and centrifuged at $2500 \mathrm{rpm}$ (IEC Centra MP4R, International Equipment Company, Needham, MA, USA) for $15 \mathrm{~min}$. The supernatant was transferred to an evaporator (Rocket Synergy evaporator, Genevac, Ipswich, $\mathrm{UK})$ to remove ethanol and water. Then, crude extracts were stored at $-80^{\circ} \mathrm{C}$ until analysis. To obtain the hydroethanolic extraction yield, a $1 \mathrm{~mL}$ extract sample was placed in preweighed test tubes, weighed, evaporated in a hot air oven (Shel Lab 1330 FX, Sheldon Manufacturing Inc., Cornelius, OR, USA) at $130^{\circ} \mathrm{C}$ for $60 \mathrm{~min}$, cooled down in a desiccator, and weighed again. The solid extraction yield was calculated as

$$
Y(\%)=\frac{g \text { of dry extract obtained from } 1 \mathrm{~mL} \text { sample } *(\mathrm{~mL} \text { of total extract })}{g \text { dry seaweed }} * 100
$$

Three extractions were run for each seaweed sample.

2.5. Total Phenolic Content (TPC). TPC was measured using the Folin-Ciocalteu method [53], where $200 \mu \mathrm{L}$ of each liquid seaweed extract (eventually after some dilution) was transferred into a $1.5 \mathrm{~mL}$ Eppendorf tube and mixed with $50 \mu \mathrm{L}$ of Folin-Ciocalteu $(2 \mathrm{M})$ reagent and $750 \mu \mathrm{L}$ of sodium carbonate $(7.5 \% \mathrm{w} / \mathrm{v})$. The mixture was homogenized for $15 \mathrm{~s}$ in a vortex (Standard Heavy-Duty Vortex Mixer VWR, Radnor, PA, USA), after which the tubes were allowed to stand in complete darkness for $2 \mathrm{~h}$ and centrifuged at $2500 \mathrm{rpm}$ for $15 \mathrm{~min}$. $200 \mu \mathrm{L}$ of each sample reaction was transferred to a 96-well microplate, and absorbance was registered at $620 \mathrm{~nm}$ in a microplate reader (Epoch 2, BioTek Instruments Inc, Winooski, VT, USA). TPC was determined by comparison of the values obtained with the calibration curve of phloroglucinol using a seven-point calibration curve ( 0 to $\left.1.25 \mathrm{mg} \mathrm{mL}^{-1}\right)$. Results were expressed as g of phloroglucinol equivalents (PGE) per $100 \mathrm{~mL}$ of dry extract or per $100 \mathrm{~g}$ of dry seaweed by considering an average of $140 \mathrm{~mL}$ hydroethanolic extract obtained from a $10 \mathrm{~g}$ seaweed meal sample.
2.6. Proximal Composition of Seaweed Extracts. These analyses were performed for all extracts following the methods described above. In addition, polysaccharide content of each extract was determined using the method described by Tako et al. [54]. Ethanol $(4: 1 \mathrm{v} / \mathrm{v}$ ratio $)$ was added to the hydroethanolic liquid extract to precipitate the polysaccharides. After that, samples were centrifuged for $10 \mathrm{~min}$ at $3500 \mathrm{rpm}$, the supernatant filtered, and the precipitate dried overnight at $60^{\circ} \mathrm{C}$ and weighed. Data were expressed as $\%$ of dry extract.

2.7. Antioxidant Capacity. DPPH free radical-scavenging activity was determined following the methodology described by García-Becerra et al. [55]: $100 \mu \mathrm{L}$ of the extract serial dilutions using ethanol $50 \%(1: 1)$ and $100 \mu \mathrm{L}$ of methanol-DPPH solution $\left(20 \mu \mathrm{g} \mathrm{mL}^{-1}\right)$ were transferred in a 96-well microplate. Samples were incubated for $30 \mathrm{~min}$ at room temperature, and absorbance was measured at $550 \mathrm{~nm}$ (Epoch 2, BioTek Instruments Inc., Winooski, VT, USA). The $\mathrm{IC}_{50}$ (i.e., the concentration of antioxidant required to cause a $50 \%$ reduction in the original DPPH concentration) was calculated using a dose-inhibition curve in a linear range by plotting the extract concentration $\left(\mathrm{mg} \mathrm{mL}^{-1}\right)$ versus the 
corresponding scavenging effect. The oxygen radical absorbance capacity (ORAC) was determined as described by Ou et al. [56]. Briefly, aliquots of $25 \mu \mathrm{L}$ seaweed extract were diluted in $75 \mathrm{mM}$ phosphate buffer and transferred to a 96well round opaque bottom microplate. Reaction fluorescence was measured using a Synergy HT microplate reader with an auto dispenser (BioTek, Instruments, Winooski, VT, USA) at a wavelength of $485 \mathrm{~nm}$ (excitation) and $580 \mathrm{~nm}$ (emission) at intervals of $70 \mathrm{~s}$ for 70 minutes. Equipment was programmed to dispense $200 \mu \mathrm{L}$ of $0.96 \mu \mathrm{M}$ fluorescein and $75 \mu \mathrm{L}$ of $95.8 \mu \mathrm{M}$ AAPH (2,2'-azobis (2-amidinopropane) dihydrochloride) used as free radical. Protective effects of experimental and control samples were calculated by subtracting the net integrated area under the curve (AUC) of the control from that of the experimental sample (AUC sample-AUC control). Results were quantified using Trolox as standard and expressed as Trolox equivalents (TE) millimolar concentration: mmol TE/g dry mass seaweed extract.

2.8. Glycosidase Inhibitory Enzyme Activities. Inhibitory activity for $\alpha$-amylase was obtained following the method of Kazeem et al. [57] by using different concentrations of the dry extract $\left(200,400,600,800,1000\right.$, and $\left.1200 \mu \mathrm{g} \mathrm{mL}^{-1}\right)$ and using acarbose $\left(200,400,600,800,1000\right.$, and $\left.1200 \mu \mathrm{g} \mathrm{mL}^{-1}\right)$ as a positive control. Briefly, tubes containing $250 \mu \mathrm{L}$ acarbose $\left(1 \mathrm{mg} \mathrm{mL}^{-1}\right)$ or seaweed extract along with a sodium phosphate buffer (0.02 M pH 6.9) or $500 \mu \mathrm{L} \alpha$-amylase solution in a phosphate buffer (with $0.006 \mathrm{M}$ de $\mathrm{NaCl}, 13 \mathrm{U}$ $\mathrm{mL}^{-1}$ ) were preincubated at room temperature for $10 \mathrm{~min}$ with $250 \mu \mathrm{L} 1 \%$ starch solution (sodium phosphate buffer). Tubes were then boiled for 5 minutes after adding $1 \mathrm{~mL}$ of DNS (method of Miller, 1959) [58] to stop the reaction. Samples were diluted in $10 \mathrm{~mL}$ of distilled water, and absorbance was measured at $540 \mathrm{~nm}$ (UNICO S1200, Dayton, NJ, USA). $\alpha$-Amylase inhibition was calculated using equation (2), where $K=$ absorbance of control blank, $S 1=$ absorbance of sample with enzyme, and $S 0=$ absorbance of sample without enzyme. Inhibitory activity was expressed as the concentration allowing half maximal inhibitory activity $\left(\mathrm{IC}_{50}\right)$. The $\mathrm{IC}_{50}$ value of each extract was determined from the plots of percent inhibition versus inhibitor concentration.

$$
\operatorname{inhibition}(\%)=\frac{K-(S 1-S 0)}{K} * 100 .
$$

The $\alpha$-glucosidase test was performed using different extract concentrations $(200,400,600,800,1000$, and $1200 \mu \mathrm{g}$ $\mathrm{mL}^{-1}$ ), as described by Mayur et al. [59]. Rat intestinal acetone powder was mixed with distilled water $\left(10 \mathrm{mg} \mathrm{mL}^{-1}\right)$ and centrifuged for $10 \mathrm{~min}$ at $10,000 \mathrm{rpm}$. The assay buffer was $100 \mathrm{mM}$ HEPES at $\mathrm{pH} 6.8$, and the substrate was $2 \mathrm{mM}$ 4 -nitrophenyl- $\alpha$-d-glucopyranoside. The assay constituents were added to 96-well microplates in the following order: $100 \mu \mathrm{L}$ of enzymatic solution $(10 \mathrm{mg}$ rat intestinal acetone powder per $1 \mathrm{~mL}$ distilled water), then $50 \mu \mathrm{L}$ of acarbose or seaweed extract or buffer, and finally $50 \mu \mathrm{L}$ of substrate. Samples were incubated at $25^{\circ} \mathrm{C}$ for 2 hours. Absorbance was recorded at the beginning and end of the incubation time at
$405 \mathrm{~nm} . \quad \alpha$-Glucosidase inhibition was calculated using equation (2). Acarbose $\left(1 \mathrm{mg} \mathrm{mL}^{-1}\right)$ was used as a positive control. The inhibitory activity was expressed as the concentration required to obtain half maximal inhibitory activity $\left(\mathrm{IC}_{50}\right)$. Extracts' $\mathrm{IC}_{50}$ values were determined from the plots of percent inhibition versus inhibitor concentration.

\subsection{Preliminary Identification of Possible Active Compounds}

2.9.1. Identification of Major Phlorotannins in Seaweed Extracts. Identification of major phlorotannins was performed by high-performance liquid chromatography (Agilent Technologies 1200 series chromatograph, Santa Clara, CA, USA) coupled with a diode array detector (HPLC$\mathrm{DAD})$. The analysis was carried out on a Luna C18 column $(250 \mathrm{~mm} \times 4.6 \mathrm{~mm}, 5 \mu \mathrm{m}$ particle size, Phenomenex, Macclesfield, UK) at a flow rate of $0.8 \mathrm{~mL} \mathrm{~min}{ }^{-1}$ (injection volume $10-20 \mu \mathrm{L}$ ). The isocratic mobile phase consisted of water acidified with $1 \%$ of formic acid. Spectral data from all peaks were accumulated in the range $230-550 \mathrm{~nm}$, and chromatograms were recorded at $270 \mathrm{~nm}$. Chromatographic data were collected using Chemstation for LC software (Hewlett-Packard-Agilent Technologies, Waldbronn, Germany). Phloroglucinol was used as a standard to quantify bioactive compounds by linear regression. The concentration of bioactive phenolic compounds $(n=3)$ was expressed as $\mu \mathrm{g}$ of PGE per mL extract, using equation (3) as the calibration curve $\left(R^{2}=0.9996\right)$ :

$$
y=24112 x-2.0812 .
$$

The same chromatographic conditions described above were used to identify bioactive compounds by HPLC coupled to time-of-flight mass spectrometry (MS-TOF) technique (G1969A, Agilent Technologies 1100, Santa Clara, CA, USA). Mass spectra were collected using electrospray source in the positive mode (ESI+) under the following conditions: $m / z$ range 100 to 1500 , nitrogen gas, gas temperature $300^{\circ} \mathrm{C}$, drying gas flow rate $8 \mathrm{~L} / \mathrm{min}$, nebulizer pressure $20 \mathrm{psi}$, capillary voltage $4000 \mathrm{~V}$, and fragmentor voltage $70 \mathrm{~V}$. Extracted ion chromatograms were obtained using the Analyst QS 1.1 software (Applied Biosystems, Carlsbad, CA, USA) and considering the accurate mass from each compound or its adducts with $\mathrm{Na}$ or $\mathrm{K}$ with an error range of 0.01 units. Mass spectra were used to identify the different phenolic compounds based on their fragmentation patterns, which were subsequently compared to previous studies $[21,22]$ and verified.

2.9.2. Sulfated Polysaccharides. Identification of the principal functional groups in sulfated polysaccharides present in the dry hydroethanolic seaweed extracts was done using a Fourier transform infrared (FT-IR) spectroscopy (Perkin Elmer Spectrum-ONE, Shelton, CT, USA, equipped with an attenuated total reflectance sampling device (ATR)). Spectra samples (including the standards alginic acid, laminarin, and fucoidan) with any previous preparation were recorded between the 4000 and $650 \mathrm{~cm}^{-1}$ range (10 scans, pressure 90-100 Gauges at room temperature) and the analytical 
TABLE 1: Proximal composition (\% dry matter, except for moisture) and total phenolic content (TPC as g PGE per $100 \mathrm{~g}$ dry matter) of five brown seaweeds collected from Baja California.

\begin{tabular}{|c|c|c|c|c|c|c|}
\hline & Moisture* & Ash & Lipid & Protein Nx6.25 & $\mathrm{NFE}^{* *}$ & TPC \\
\hline S. compressa & $10.9 \pm 0.1 b$ & $24.9 \pm 0.9 b$ & $2.93 \pm 0.10 c$ & $10.4 \pm 0.6 \mathrm{bc}$ & $61.8 \pm 0.9 \mathrm{~b}$ & $8.32 \pm 0.39 \mathrm{e}$ \\
\hline C. osmundacea & $10.6 \pm 0.1 b$ & $33.9 \pm 0.5 \mathrm{~d}$ & $1.08 \pm 0.07 b$ & $9.1 \pm 0.1 \mathrm{a}$ & $55.9 \pm 0.3 \mathrm{a}$ & $3.98 \pm 0.17 c$ \\
\hline E. arborea & $9.2 \pm 0.3 \mathrm{a}$ & $23.0 \pm 0.5 \mathrm{a}$ & $0.56 \pm 0.12 \mathrm{a}$ & $11.1 \pm 0.4 \mathrm{~cd}$ & $65.4 \pm 0.5 c$ & $5.00 \pm 0.18 \mathrm{~d}$ \\
\hline P. californica & $13.4 \pm 0.7 \mathrm{c}$ & $30.1 \pm 0.1 c$ & $0.55 \pm 0.12 \mathrm{a}$ & $9.6 \pm 0.9 \mathrm{ab}$ & $59.7 \pm 1.1 \mathrm{~b}$ & $1.88 \pm 0.04 \mathrm{~b}$ \\
\hline E. menziesii & $12.5 \pm 0.5 c$ & $33.1 \pm 1.0 \mathrm{~d}$ & $0.67 \pm 0.05 a$ & $11.8 \pm 0.5 \mathrm{~d}$ & $54.4 \pm 1.1 \mathrm{a}$ & $0.53 \pm 0.02 \mathrm{a}$ \\
\hline$F$ value & 48.890 & 161.33 & 317.637 & 15.867 & 83.206 & 109.013 \\
\hline Sig. ANOVA & $<0.001$ & $<0.001$ & 0.001 & $<0.001$ & $<0.001$ & $<0.001$ \\
\hline
\end{tabular}

${ }^{*}$ Moisture in the ground seaweed sample; ${ }^{* *}$ nitrogen-free extract, by difference NFE (100-ash + lipid + protein contents); different letters in a column indicate different homogeneous subsets as defined by a multiple means comparison test (Tukey).

spectral range from 1700 to $650 \mathrm{~cm}^{-1}$ in transmittance mode. A background spectrum air was scanned under the same instrumental condition before each series of measurements.

2.10. Statistical Analysis. Each variable was determined in triplicate. All reported data were expressed as mean\pm standard deviation and submitted to one-way ANOVA statistical analysis and Tukey's posttest $(P<0.05)$ using SPSS Software, version 20 (IBM Corporation, Armonk, NY, USA). Correlations ( $r$-Pearson correlation coefficient) between activities and chemical compounds present in seaweed extracts were determined using Microsoft Excel.

\section{Results and Discussion}

3.1. Proximal Composition and Total Polyphenol Content in Seaweeds. The chemical composition of the seaweed samples presented in Table 1 agreed with previous information reported for brown seaweeds [60, 61]. S. compressa, E. arborea, and E. menziesii presented the highest protein contents, ranging from 10 to $12 \% \mathrm{DM}$, agreeing with the values $(8-12 \%)$ reported for the same species in previous studies $[45,47]$. In contrast, $C$. osmundacea and $P$. californica presented a lower protein content (9-10\% DM), but no previous studies were available for comparison. Lipid content in all seaweed species was low, as expected: $S$. compressa had the highest lipid content (2.93\% DM), followed by $C$. osmundacea (1\% DM), while E. arborea, $P$. californica, and E. menziesii were very poor in lipids $(0.6 \%$ $\mathrm{DM})$. These values coincide with those previously reported for E. arborea (0.19\%) [45] and E. menziessi (0.14\%) [47], but not for S. compressa, which had twice the content $(1.46 \%)$ reported by Guerra-Rivas [47]. Ashes and carbohydrates were the major compounds in all seaweeds, ranging between 23-34\% and 54-65\% DM, respectively. E. arborea and S. compressa presented the lowest ash (23 and 25\%) and the highest NFE (62 and 65\%) contents, respectively, while the other three algae were richer in ashes (30-34\%) and poorer in NFE (54-59\%). These results coincide with previously reported values for E. arborea (27.2 ash and 55.30\% NFE $+5.04 \%$ fibre) [45], S. compressa (15.9\% ash and 50.6\% NFE $+6.47 \%$ fibre), and E. menziessi (28.9\% ash and $40 \mathrm{NFE}$ $+7.2 \%$ fibre) [47]. They are also in accordance with the high total dietary fibre content recently reported by Tapia-Salazar et al. [46] for S. compressa and E. arborea (59 and 55\% DM, respectively).

In the case of seaweed TPC, S. compressa and E. arborea also had the highest concentrations (8.32 and 5 PGE per $100 \mathrm{~g}$ dry seaweed), followed by C. osmundacea (4\%), P. californica (1.9\%), and finally E. menziesii, which distinguished itself for having the lowest content $(0.53 \%)$ (Table 1). E. arborea TPC was in the high range compared to Japanese E. arborea and E. bicyclis, 60\% methanol extracted (2.7-6.6 g PGE per $100 \mathrm{~g}$ dry seaweed) [62]. TPC in $S$. compressa was higher than the previously reported concentration for the same species (formerly known as Pelvetia fastigata) extracted with $80 \%$ methanol (5.2 to $6 \mathrm{~g}$ PGE per $100 \mathrm{~g}$ dry seaweed) [63]. C. osmundacea presented higher TPC when compared to methanol extracts of $C$. neglecta and C. osmundacea (1.37 and $1.60 \mathrm{~g}$ PGE per $100 \mathrm{~g}$ dry seaweed) [63]. TPC of Egregia menziesii was within the values previously reported for methanol extracts $(0.36$ to $2.16 \mathrm{~g}$ PGE per $100 \mathrm{~g}$ dry seaweed) [63]. In the case of $P$. californica, no previous studies for TPC were found. Differences in TPC between this and previous studies could be attributed to several factors such as seaweed collection area, season, drying method, solvents, and extraction conditions. In summary, among the five species studied, S. compressa and E. arborea had the highest carbohydrate and phenolic contents.

3.2. Seaweed Hydroethanolic Extracts. Extraction yield, proximal composition, and total phenolic content of hydroethanolic extracts were significantly different between seaweed species $(P<0.001$, Table 2$)$. The best extraction yield (32.8\% of dry seaweed) was obtained from E. arborea, while the mass yield for E. menziesii, P. californica, C. osmundacea, and $S$. compressa was very similar and ranged from 17.5 to $20.3 \%$. Under the extraction conditions used in this study, $50 \%$ ethanol efficiently extracted inorganic and organic polar compounds, resulting in seaweed extracts consisting of minerals (17 to $59 \% \mathrm{DM}$ ), proteins (4.23 to $9.30 \% \mathrm{DM}$ ), lipids (5 to $12 \% \mathrm{DM}$ ), soluble polysaccharides (5.4 to $53.2 \%$ DM), NFE (16.9 to $70.1 \%$ DM), and polyphenols (2.6 to $47.7 \%$ PGE DM). These results fall within the ranges previously reported for $60 \%$ ethanol extracts from $L$. cichorioides, C. costata, and F. evanescens [64] (24 to $60 \%$ ash, 4 to $8 \%$ protein, $1.4-10.1 \%$ PGE, 23 to $67 \%$ NFE, 3.6-12\% lipophilic matter), except for polyphenol 
TABLE 2: Extraction yield (\% seaweed dry matter), proximal composition of the extracts (\% extract dry matter, except for moisture), and their total phenolic content (TPC as g PGE per $100 \mathrm{~g}$ extract dry matter).

\begin{tabular}{lcccccccc}
\hline Seaweed & Extraction yield & Moisture & Ash & Lipid & Protein Nx6.25 & Polysaccharides & NFE* & TPC \\
\hline S. compressa & $17.5 \pm 0.8 \mathrm{a}$ & $14.7 \pm 1.1 \mathrm{c}$ & $26.4 \pm 2.4 \mathrm{~b}$ & $7.0 \pm 0.8 \mathrm{a}$ & $9.3 \pm 0.2 \mathrm{c}$ & $19.7 \pm 1.9 \mathrm{~b}$ & 57.3 & $47.7 \pm 2.2 \mathrm{e}$ \\
C. osmundacea & $19.2 \pm 1.7 \mathrm{a}$ & $10.5 \pm 0.3 \mathrm{a}$ & $59.1 \pm 3.7 \mathrm{c}$ & $12.3 \pm 1.1 \mathrm{c}$ & $4.2 \pm 0.1 \mathrm{a}$ & $11.2 \pm 1.0 \mathrm{a}$ & 24.4 & $20.7 \pm 0.9 \mathrm{~d}$ \\
E. arborea & $32.8 \pm 1.9 \mathrm{~b}$ & $19.7 \pm 0.4 \mathrm{~d}$ & $17.1 \pm 2.7 \mathrm{a}$ & $5.0 \pm 0.5 \mathrm{a}$ & $7.7 \pm 0.5 \mathrm{~b}$ & $53.2 \pm 3.9 \mathrm{~d}$ & 70.2 & $15.2 \pm 0.5 \mathrm{c}$ \\
P. californica & $19.8 \pm 1.8 \mathrm{a}$ & $12.5 \pm 0.5 \mathrm{~b}$ & $31.7 \pm 3.8 \mathrm{~b}$ & $10.1 \pm 0.8 \mathrm{~b}$ & $6.8 \pm 0.7 \mathrm{~b}$ & $28.6 \pm 2.0 \mathrm{c}$ & 51.4 & $9.5 \pm 0.2 \mathrm{~b}$ \\
E. menziesii & $20.3 \pm 0.3 \mathrm{a}$ & $12.5 \pm 0.7 \mathrm{~b}$ & $52.8 \pm 3.2 \mathrm{c}$ & $9.6 \pm 0.6 \mathrm{~b}$ & $9.2 \pm 0.5 \mathrm{c}$ & $5.4 \pm 0.9 \mathrm{a}$ & 28.4 & $2.6 \pm 0.1 \mathrm{a}$ \\
F value & 106.351 & 86.139 & 94.327 & 40.099 & 66.684 & 212.364 & - & 744.081 \\
Sig. ANOVA & $<0.001$ & $<0.001$ & $<0.001$ & $<0.001$ & $<0.001$ & $<0.001$ & - & $<0.001$ \\
\hline
\end{tabular}

${ }^{*} \mathrm{NFE}$ (nitrogen free extract) calculated by difference.

TABLE 3: Antioxidant activities and half maximal inhibitory concentrations of hydroethanolic seaweed extracts against $\alpha$-amylase and $\alpha$-glucosidase.

\begin{tabular}{|c|c|c|c|c|c|c|}
\hline $\begin{array}{l}\text { Hydroethanolic } \\
\text { extract }\end{array}$ & $\begin{array}{c}\mathrm{DPPH} \\
\mathrm{IC}_{50} \mathrm{mg} \mathrm{mL}^{-1}\end{array}$ & $\begin{array}{c}\text { ORAC } \\
\text { mmol TE g }^{-1}\end{array}$ & $\begin{array}{c}\alpha \text {-Amylase } \\
\mathrm{IC}_{50} \mu \mathrm{g} \mathrm{mL}^{-1}\end{array}$ & $\begin{array}{c}\alpha \text {-Amylase } \\
\mathrm{IC}_{10} \mu \mathrm{g} \mathrm{mL}^{-1}\end{array}$ & $\begin{array}{c}\alpha \text {-Glucosidase } \\
\mathrm{IC}_{50} \mu \mathrm{g} \mathrm{mL}^{-1}\end{array}$ & $\begin{array}{c}\alpha \text {-Glucosidase } \\
\mathrm{IC}_{10} \mu \mathrm{g} \mathrm{mL}^{-1}\end{array}$ \\
\hline S. compressa & $3.73 \pm 0.11 c$ & $0.817 \pm 0.07 c$ & $940.1 \pm 8.3 \mathrm{a}$ & 240 & $194.2 \pm 16.1 \mathrm{a}$ & 40 \\
\hline C. osmundacea & $4.20 \pm 0.36 c$ & $0.257 \pm 0.01 \mathrm{a}$ & $>1200$ & 2000 & $>1200$ & 105 \\
\hline E. arborea & $1.67 \pm 0.15 b$ & $0.801 \pm 0.03 c$ & $1152 \pm 19.9 b$ & 840 & $646.8 \pm 0.7 b$ & 65 \\
\hline P. californica & $8.07 \pm 0.50 \mathrm{~d}$ & $0.542 \pm 0.05 b$ & $>1200$ & 170 & $>1200$ & 105 \\
\hline E. menziesii & $0.93 \pm 0.12 \mathrm{a}$ & $0.192 \pm 0.01 \mathrm{a}$ & $>1200$ & 920 & $>1200$ & 420 \\
\hline Acarbose & - & - & 152.9 & & 184.1 & \\
\hline$F$ value & 269.2 & 218.3 & 596.7 & & 3148.3 & \\
\hline Sig. ANOVA & $<0.001$ & $<0.001$ & $<0.001$ & & $<0.001$ & \\
\hline
\end{tabular}

PGE: phloroglucinol equivalents; DS: dry seaweed; TE: Trolox equivalents; $\mathrm{IC}_{50}$ : the half maximal inhibitory concentration. Each value represents the average of three analytical replicates with standard deviation. Different letters (down column) represent significant differences at $P<0.05$.

compounds, which were higher in our extracts. Nevertheless, direct comparison to other studies is complicated due to potential differences in solvent type, concentration, seaweed/solvent volume ratio, extraction methods, and species tested, which influence the extracts moisture, minerals, polysaccharide and polyphenol content, and the extraction yield.

E. arborea and S. compressa extracts presented a proximal composition very similar to that of the dried seaweed. These seaweed extracts presented the highest polysaccharide (53 and 20\%, respectively), NFE (70.1 and 57.3\%, respectively), phenolic (15.2 and 47.7\% PGE, respectively), and protein (11.1 and 10.4\%) contents. In the case of $C$. osmundacea and E. menziesii extracts, minerals were the predominant compounds and the lipophilic matter content was elevated. Finally, $P$. californica extract had a mild carbohydrate, low phenol content, and high lipid content (Table 2).

3.3. Antioxidant Activity. The five macroalgae extracts were evaluated as radical scavengers against $\mathrm{DPPH}$, showing significant differences $(P<0.0001)$ among $\mathrm{IC}_{50}$ values (Table 3): E. menziesii extract was the most effective $\left(\mathrm{IC}_{50} 0.93 \mathrm{mg} \mathrm{mL}^{-1}\right)$, followed by E. arborea and S. compressa extracts showing intermediate $\mathrm{IC}_{50}$ values (1.7 and $3.7 \mathrm{mg} \mathrm{mL}^{-1}$ ), and the least potent were $C$. osmundacea and $P$. californica extracts with the lowest scavenging activities $\left(\mathrm{IC}_{50} 4.2\right.$ and $\left.8.1 \mathrm{mg} \mathrm{mL}^{-1}\right)$. None of the extracts evaluated were equivalent to Trolox (DPPH $\mathrm{IC}_{50} 0.018 \mathrm{mg} \mathrm{mL}^{-1}$ ). The $\mathrm{DPPH}$ scavenging capacity of different extracts $(100 \%$ methanol) of E. arborea and C. osmundacea collected from the Baja California Peninsula has already been reported [16]: the $\mathrm{DPPH} \mathrm{IC}_{50}$ for these two species were 0.069 and $0.227 \mathrm{mg} \mathrm{mL}^{-1}$, respectively, being classified as the most potent among 17 species tested and with a similar or superior scavenging capacity than butylated hydroxytoluene (BHT) $\left(\mathrm{IC}_{50}=0.0867 \mathrm{mg} \mathrm{mL}^{-1}\right)$. Differences between these values and our results could be attributed to not only differences in solvents and extraction methodologies but also differences in collection sites and seasons. To our knowledge, DPPH $\mathrm{IC}_{50}$ values of $S$. compressa, P. californica, and E. menziesii extracts are described for the first time in this article.

The DPPH $\mathrm{IC}_{50}$ values among the seaweed extracts tested were lower (therefore, better) $\left(0.93-8.07 \mathrm{mg} \mathrm{mL}^{-1}\right)$ compared to $80 \%$ ethanolic extracts from brown seaweeds $\left(\mathrm{IC}_{50}\right.$ $>10 \mathrm{mg} \mathrm{mL}^{-2}$ ) reported by other authors [65]. However, the $\mathrm{IC}_{50}$ values observed were higher when compared to the most potent antioxidant seaweed extracts such as: E. cava $80 \%$ ethanol $\left(\mathrm{IC}_{50} 0.01 \mathrm{mg} \mathrm{mL}^{-1}\right)$ and $F$. vesiculosus $50-70 \%$ ethanol extract $\left(\mathrm{IC}_{50} 0.03 \mathrm{mg} \mathrm{mL}^{-1}\right)$ [15].

The five macroalgae hydroethanolic extracts were also able to quench oxygen-free radicals in a test tube and showed significant differences among them (Table 3). ORAC scavenging potential of the different species follows a different order than for DPPH; this is due to the presence (in each extract) of different mixtures of antioxidants, with different physicochemical properties or structural features and with different mechanisms of in vitro antioxidant activity and therefore different sensitivities for each method [34]. S. compressa and E. arborea were the most potent 
species $\left(0.82\right.$ and $0.80 \mathrm{mmol}$ TE $\mathrm{g}$ dry extract $\left.{ }^{-1}\right)$, followed by $P$. californica $\left(0.54 \mathrm{mmol} \mathrm{TE} \mathrm{g}\right.$ dry extract $\left.^{-1}\right)$ and $C$. osmundacea and E. menzziesii $(0.26$ and $0.192 \mathrm{mmol}$ TE $\mathrm{g}$ dry extract ${ }^{-1}$ ). The ORAC of the five seaweeds' hydroethanolic extracts, to our knowledge, is described herein for the first time.

ORAC values found in this study were higher than those reported for other brown seaweed species [15]. It must be noted, however, that the ORAC value for C. osmundacea was in the range of values reported for other species of the same genus: C. abies-marina $\left(0.275-1.314 \mathrm{mmol} \mathrm{TE}^{-1}\right)$ [66].

In this study, no correlation between the five seaweed extracts' TPC and DPPH radical-scavenging activity $\left(R^{2}=0.005\right)$ was observed. TPC and extract ORAC values showed a slight correlation $\left(R^{2}=0.36\right)$, but this was improved $\left(R^{2}=0.87\right)$ when $C$. osmundacea was not considered in the regression. C. osmundacea with high phenolic content displayed lower activity than expected, suggesting that other compounds were also responsible for this result. NFE extract content and ORAC radical-scavenging activity also showed a strong correlation $\left(R^{2}=0.91\right)$. The two algae extracts with the highest ORAC activities (S. compressa and E. arborea) were the richest in NFE and were among the richest in polyphenols, suggesting that in both seaweeds, carbohydrates and polyphenols were the main components working as antioxidants. The antioxidant effect of brown seaweed extracts rich in these two major polymeric fractions has been reported by numerous authors [24-26, 34]. The correlation between these compounds and the antioxidant activity is strong for some extracts or inexistent for others. The change in the chemical structure of these compounds during the extraction and the interferences caused by some components present in the extracts are some of the multiple reasons for which there may be variations in the correlation $[15,67,68]$.

3.4. Glycosidase Inhibition. The capacity to inhibit enzymes was different among hydroethanolic seaweed extracts. S. compressa and $E$. arborea extracts displayed the highest $\alpha$-amylase and $\alpha$-glucosidase inhibitory activities (the lowest $\mathrm{IC}_{50}$ ) (Figures 1 and 2; Table 3). The rest of the seaweed extracts were inefficient at inhibiting $50 \%$ of both glycosidase activities $\left(\mathrm{IC}_{50}>1200 \mu \mathrm{g} \mathrm{mL}^{-1}\right)$. The $\mathrm{IC}_{50}$ values against $\alpha$-amylase and $\alpha$-glucosidase were $940.1 \mu \mathrm{g} \mathrm{mL}^{-1}$ and $194.2 \mu \mathrm{g} \mathrm{mL}^{-1}$, respectively, for $S$. compressa extract, and 1151.8 and $646.8 \mu \mathrm{g}$ $\mathrm{mL}^{-1}$, respectively, for that of E. arborea. Values found for acarbose, the positive control in this study (152.9 and $184.1 \mu \mathrm{g}$ $\mathrm{mL}^{-1}$ respectively), were close to values observed in previous studies $[29,32]$. In comparison to acarbose, $S$. compressa and $E$. arborea showed poor inhibitory efficiencies against $\alpha$-amylase (16 and 13\%). In contrast, S. compressa extract was almost as effective as acarbose (95\%) in inhibiting glucosidase, while $E$. arborea extract was less effective, displaying $28 \%$ of the acarbose activity. To our knowledge, $\alpha$-glucosidase or $\alpha$-amylase inhibitory activity of the five seaweed extracts evaluated in this work is described here for the first time.

Currently, there is not much information about other Silvetia species' capacity to inhibit amylase activity; an $\mathrm{IC}_{50}$ value reported for a Pelvetia caniculata ethanol: water $(80: 20)$

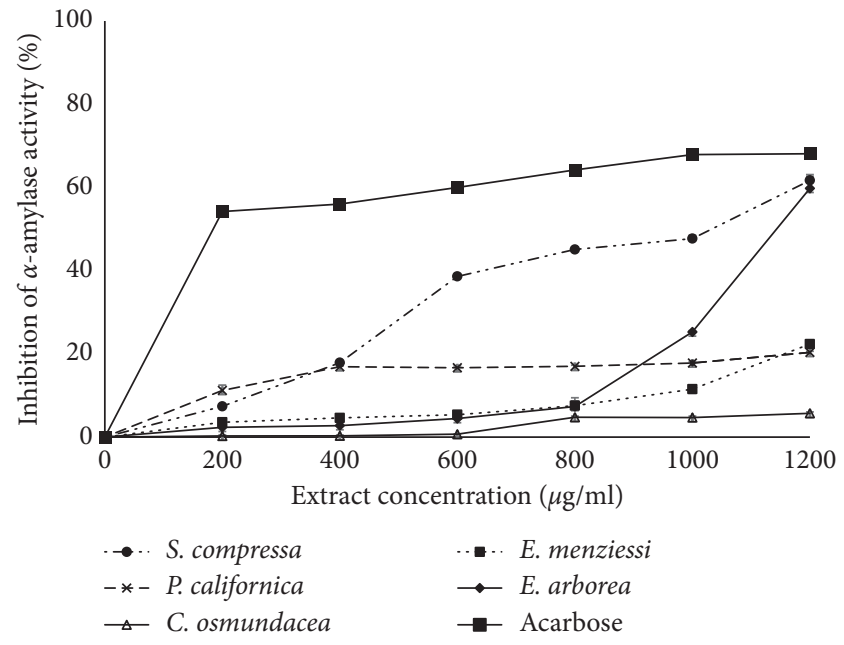

FIGURE 1: $\alpha$-Amylase inhibitory activities of different concentrations of ethanolic extracts from Silvetia compressa, Cystoseira osmundacea, Ecklonia arborea, Pterygophora californica, and Egregia menziesii. Data are mean \pm SE $(n=3)$.

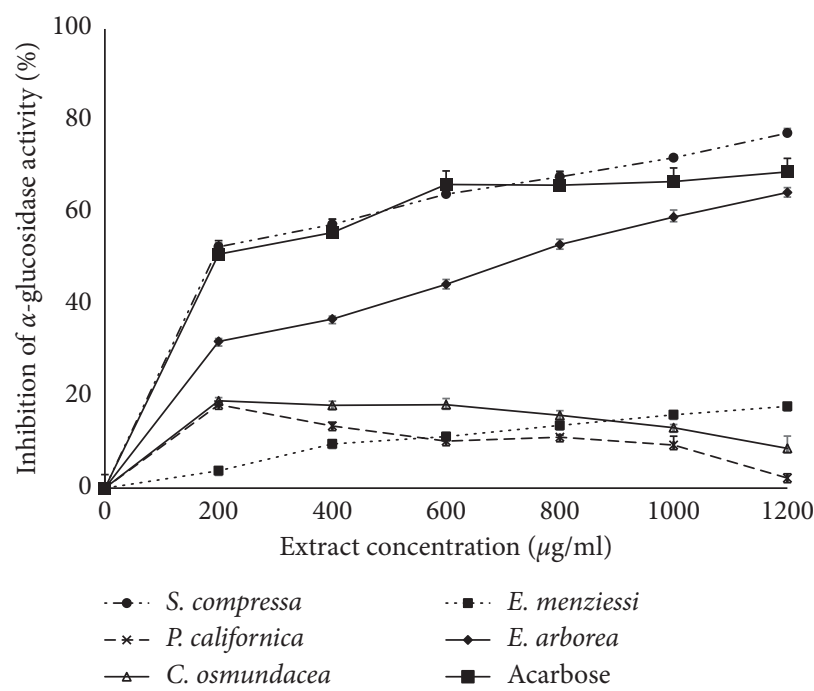

FIGURE 2: $\alpha$-Glucosidase inhibitory activities of different concentrations of ethanolic extracts from Silvetia compressa, Cystoseira osmundacea, Ecklonia arborea, Pterygophora californica, and Egregia menziesii. Data are mean \pm SE $(n=3)$.

extract $(51.0 \mu \mathrm{g} / \mathrm{mL})$ was almost twenty times lower [19]. In contrast, Ecklonia species have been recognized as good sources of carbohydrase inhibitors. Moon et al. [69] examined the effect of methanolic extracts (ethyl acetate fraction) from two Ecklonia (Eisenia) species, E. stolonifera and E. bicyclis, on $\alpha$-glucosidase activity and found that their inhibitory effect was substantially stronger than that of acarbose. $\alpha$-Amylase $\mathrm{IC}_{50}$ was $>500 \mu \mathrm{g} \mathrm{mL}^{-1}$ for E. bicyclis (85.3 $\mathrm{mg} \mathrm{PGE} \mathrm{g}^{-1}$ dry weight) [18].

When comparing $\mathrm{IC}_{50}$ values of our seaweed extracts with those reported for the ethanolic extracts of other species, S. compressa and E. arborea hydroethanolic extracts were relatively ineffective as $\alpha$-amylase inhibitors. 
TABLE 4: Fragments adducts, $\lambda$ max, and molar mass of most abundant phlorotannins identified by HPLC-DAD and HPLC-MS-TOF methodologies for the hydroethanolic extracts of seaweeds collected from Baja California.

\begin{tabular}{|c|c|c|c|c|c|}
\hline & Peak\# & 1 & 2 & 3 & 4 \\
\hline & Bioactive compound & Phloretol & Fucophlorethol & $\begin{array}{l}\text { Two units of } \\
\text { phloroglucinol }\end{array}$ & $\begin{array}{l}\text { Three units of } \\
\text { phloroglucinol }\end{array}$ \\
\hline & $\lambda \max (\mathrm{nm})$ & 220,262 & 220,270 & 220,268 & 220,267 \\
\hline & Molar mass & 274.1231 & 374.0555 & 252.0809 & 378.1241 \\
\hline & $\begin{array}{c}\text { Fragment } \\
\text { adducts }(m / z)\end{array}$ & $\begin{array}{c}275.1299 \mathrm{M}+\mathrm{H} \\
276.134 \mathrm{M}+\mathrm{H}+1 \\
297.1118 \mathrm{M}+\mathrm{Na} \\
313.0888 \mathrm{M}+\mathrm{K}\end{array}$ & $\begin{array}{c}\text { 375.0627 M+H, } \\
376.0679 \mathrm{M}+\mathrm{H}+1 \\
377.0613 \mathrm{M}+\mathrm{H}+2\end{array}$ & $\begin{array}{c}253.0876 \mathrm{M}+\mathrm{H} \\
254.0904 \mathrm{M}+\mathrm{H}+1 \\
275.0719 \mathrm{M}+\mathrm{Na}\end{array}$ & $\begin{array}{c}190.0693 \mathrm{M}+2 \mathrm{H} \\
190.5667 \mathrm{M}+2 \mathrm{H}+1\end{array}$ \\
\hline \multirow{8}{*}{$\begin{array}{l}\mu \mathrm{g} \text { phloroglucinol } \\
\text { equivalents } \mathrm{ml}^{-1} \\
\text { extract }\end{array}$} & Silvetia compressa & $19.1 \pm 1.5 \mathrm{a}$ & $71.2 \pm 2.5 \mathrm{~d}$ & $480.9 \pm 4.7 c$ & $152.7 \pm 3.2 \mathrm{~d}$ \\
\hline & Cystoseira osmundacea & $37.1 \pm 2.1 b$ & $24.8 \pm 0.8 b$ & $29.9 \pm 2.1 \mathrm{a}$ & $14.6 \pm 1.4 \mathrm{a}$ \\
\hline & Ecklonia arborea & $37.1 \pm 0.5 b$ & $25.1 \pm 1.0 \mathrm{~b}$ & NF & $117.5 \pm 4.7 \mathrm{c}$ \\
\hline & Pterygophora californica & $13.2 \pm 2.8 \mathrm{a}$ & $14.5 \pm 1.1 \mathrm{a}$ & $36.0 \pm 1.8 \mathrm{a}$ & $38.8 \pm 3.1 \mathrm{~b}$ \\
\hline & Egregia mensienzii & $42.3 \pm 2.6 b$ & $30.7 \pm 1.1 \mathrm{c}$ & $113.6 \pm 2.4 b$ & $45.5 \pm 1.2 b$ \\
\hline & References & 2 & 1 & 3 & 3 \\
\hline & $F$ values & 52.5 & 346.9 & 5034.7 & 478.9 \\
\hline & Sig. ANOVA & $<0.001$ & $<0.001$ & $<0.001$ & $<0.001$ \\
\hline
\end{tabular}

${ }^{1}$ Isaza Martínez and Torres Castañeda [21]; ${ }^{2}$ Steevensz et al. [20]; ${ }^{3}$ Tierney et al. [22]. NF: not found.

For example, $\mathrm{IC}_{50}$ values for $A$. nodosum, F. serratus, $F$. vesiculosus, $P$. caniculata and $F$. spiralis ethanolic extracts ( $80: 20)$ were 10 to 20 times lower: $44.7,70.6,59.1,51.0$, and $109 \mu \mathrm{g} \mathrm{mL}^{-1}$, respectively [19].

The potency of the $\alpha$-glucosidase inhibition produced by S. compressa extract was 2 to 22 times higher than that produced by other brown seaweed species, such as $P$. arborescens $\left(\mathrm{IC}_{50} 260 \mu \mathrm{g} \mathrm{mL}{ }^{-1}\right.$, water extract) and $H$. macroloba ( $\mathrm{IC}_{50} 4220 \mu \mathrm{g} \mathrm{mL}^{-1}$, water extract) [17]. Nonetheless, $S$. compressa extract was not as efficient as $F$. vesiculosus ethanolic extract, one of the most potent glucosidase inhibitor seaweed extracts studied to date, whose $\mathrm{IC}_{50}$ is $<0.5 \mu \mathrm{g} \mathrm{mL}^{-1}$ [19]. As previously mentioned, environmental differences, seasonal variations, differences in the extraction methods, and the degree of purity of the extracts, as well as the chemical structure and molecular weight of the active compounds may explain the differences in the potency of seaweed-derived extracts.

Since we did not obtain $\alpha$-amylase and $\alpha$-glucosidase $\mathrm{IC}_{50}$ values for every seaweed extract, the $\mathrm{IC}_{10}$ was calculated for correlation analysis with the chemical compounds present in the extracts (Table 3 ). With these values, a negative linear correlation was found for $\alpha$-amylase with NFE $\left(R^{2}=0.54\right)$ and for $\alpha$-glucosidase $\mathrm{IC}_{10}$. A negative potential correlation was found with TPC $\left(R^{2}=0.89\right)$, as well as a slight polynomial correlation with soluble polysaccharides $\left(R^{2}=0.67\right)$. Indeed, the $S$. compressa extract with the best amylase and glucosidase $\mathrm{IC}_{50}$ was the one richest in TPC and second richest in carbohydrates. On the other hand, E. arborea extract, with the second-best amylase and glucosidase activities, was the seaweed richest in carbohydrates. The ability of naturally occurring polyphenols from brown seaweeds to inhibit enzymes, including $\alpha$-amylase and $\alpha$-glucosidase, has been widely reported $[14,19,69,70]$. Furthermore, a number of these studies have demonstrated a strong correlation between phenolic content, enzyme inhibition, and antioxidant properties [19]. Recently, it has been shown that ethyl acetate fractions obtained from brown seaweeds, rich in oligomers of phloroglucinol, evidenced a pronounced inhibitory effect on $\alpha$-amylase and $\alpha$-glucosidase activities [18, 29].

Water soluble carbohydrates (e.g., fucoidan) found in great abundance in our active seaweed extracts, mainly in $E$. arborea, have also been reported as potent carbohydrase inhibitors $[32,67]$; the synergy of these two types of compounds has also been suggested. Interestingly, the enzyme inhibition activity in our extracts was lost when polysaccharides were removed from the extract by precipitation with ethanol (results not shown). Therefore, the synergistic effect of different compounds present in the hydroethanolic extract deems further research.

3.5. Phlorotannin Quantification and Identification. It has been demonstrated that phlorotannins made up more than $82 \%$ of the crude polyphenol fraction in a variety of brown seaweeds [71]. Phlorotannins are oligomers or dehydropolymers of phloroglucinols commonly known as marine algal polyphenols [71]. Main phlorotannins were detected in a positive mode $(\mathrm{M}+\mathrm{H})$ and included its protonated ions $(\mathrm{M}+\mathrm{H})^{+}$, a few of them which were present as sodium or potassium adducts. HPLC-MS-TOF allowed the identification of four main compounds in the $\mathrm{m} / \mathrm{z}$ range of 190 to $377 \mathrm{~m} / z$ (Table 4 ). To our knowledge, this is the first report of phlorotannins in our five seaweeds. The main phlorotannins detected in the seaweed extracts were phloretol, fucophloroethol, and phlorotannins with twoand three-PGU (Figure 3, Table 4). These compounds were found in all seaweed hydroethanolic extracts, with the exception of two-PGU phlorotannin that was not present in $E$. arborea. The concentration of the sum of the four major phlorotannins evaluated was highest for $S$. compressa (723.9 $\mu \mathrm{g}$ PGE per $\mathrm{mL}$ of extract), followed by E. menziesii (232.1 $\mu$ g PGE per mL of extract), E. arborea (179.7 $\mu \mathrm{g}$ PGE per $\mathrm{mL}$ of extract), C. osmundacea (101.4 $\mu \mathrm{g}$ PGE per $\mathrm{mL}$ of extract), and $P$. californica (72.5 $\mu \mathrm{g}$ PGE per $\mathrm{mL}$ of extract). 


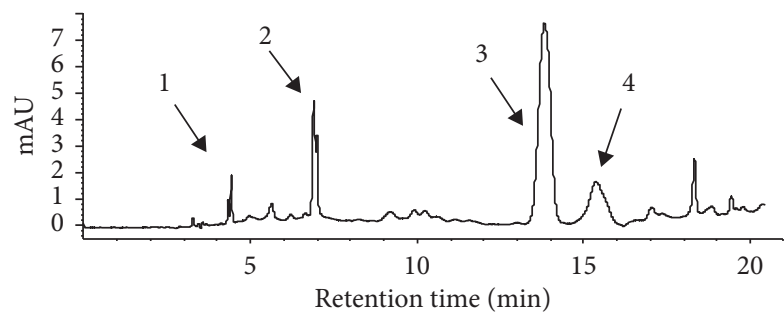

(a)

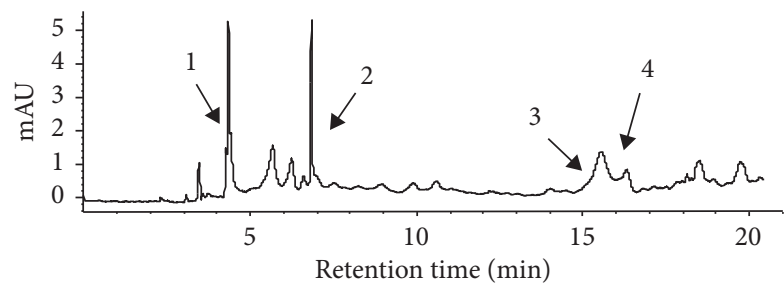

(c)

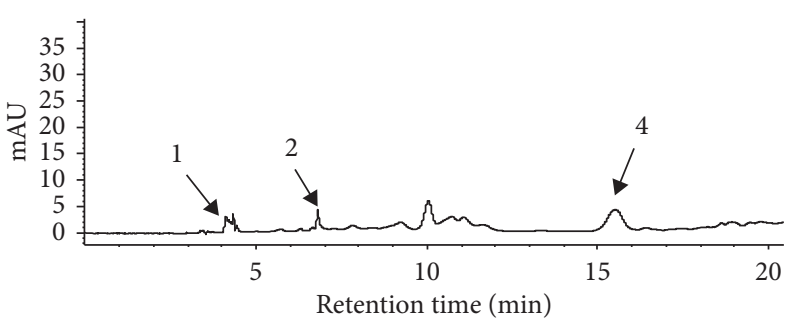

(b)

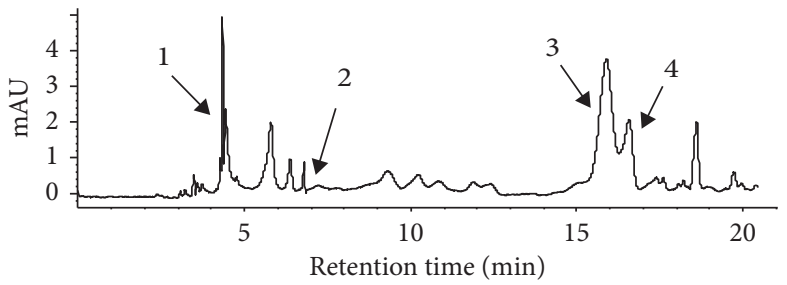

(d)

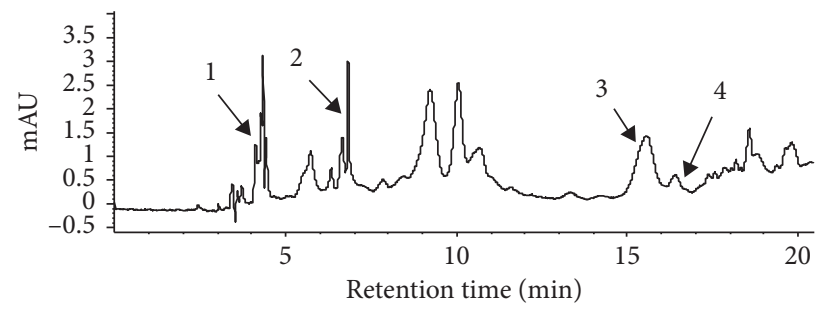

(e)

Figure 3: Chromatograms obtained at $270 \mathrm{~nm}$ from the ethanolic crude extract of (a) Silvetia compressa, (b) Ecklonia arborea, (c) Cystoseira osmundacea, (d) Egregia mensienzii, (e) Pterigophora californica. (1) Phloretol; (2) fucophloretol; (3) two units of phloroglucinol; (4) three units of phloroglucinol.

TABLE 5: Signals assigned in the ATR/FT-IR second-derivative spectrum of the hydroethanolic extracts from different brown seaweeds and fucoidan, laminarin, and alginate standards.

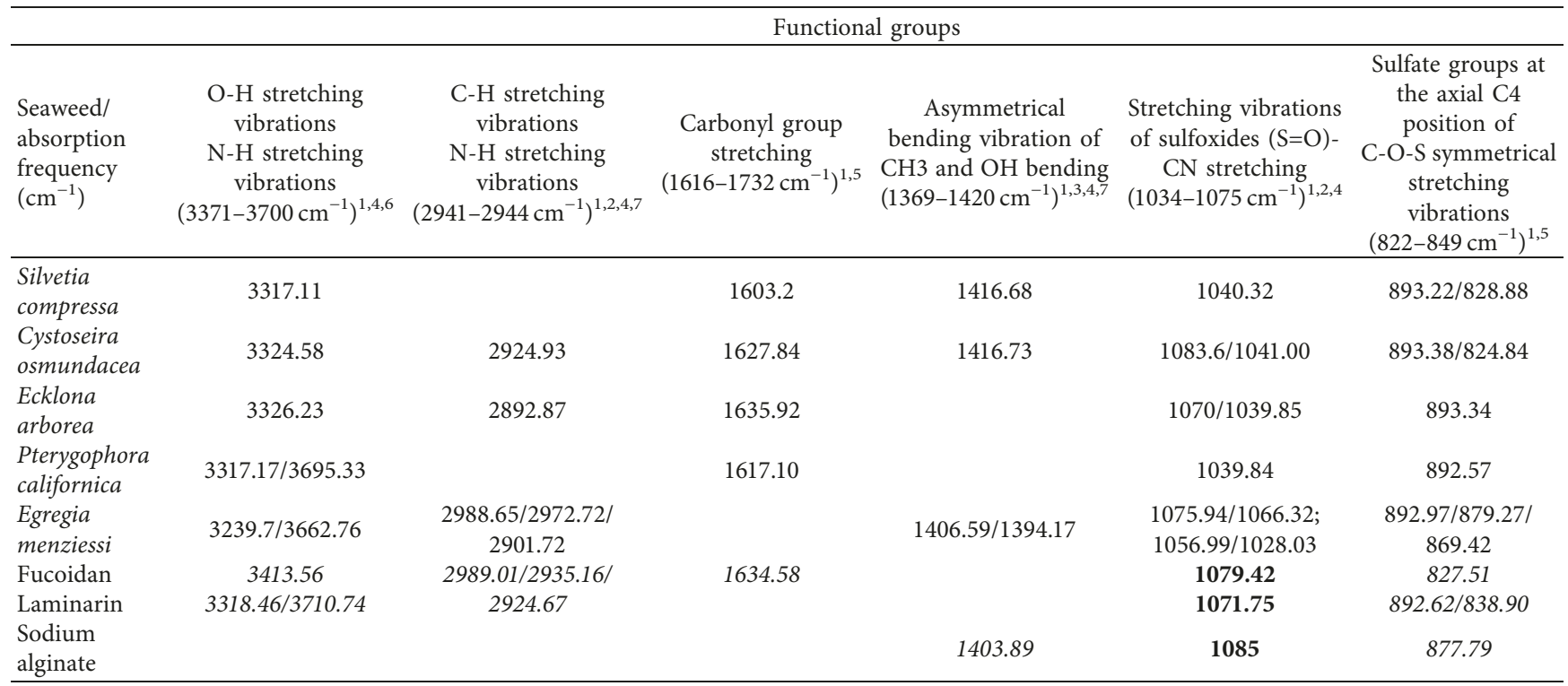

${ }^{1}$ Lim et al. [73]; ${ }^{2}$ Park et al. [74]; ${ }^{3}$ Yee et al. [75]; ${ }^{4}$ Kannan [76]; ${ }^{5}$ Shekhar et al. [77]; ${ }^{6}$ Guo and Zhang [78]; ${ }^{7}$ 'Souza et al. [79]. 


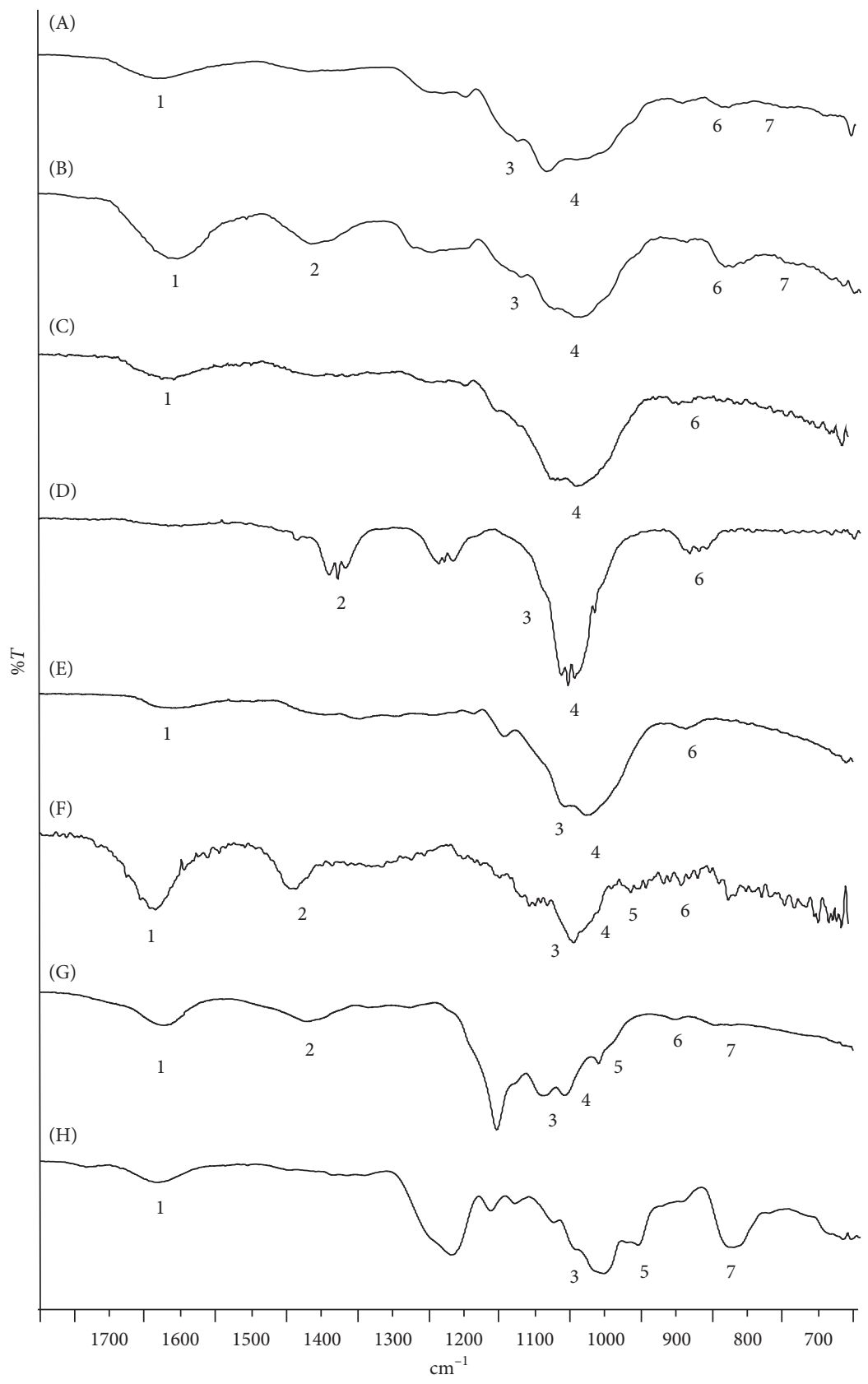

(a)

FIgURE 4: Continued. 


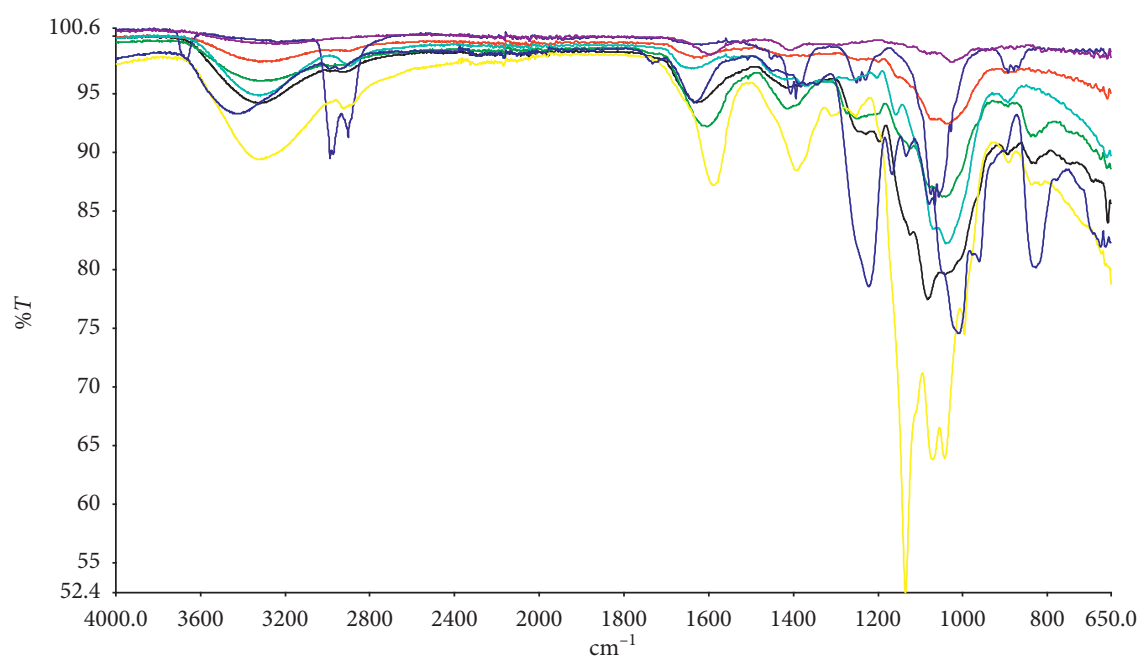

(b)

FIGURE 4: (a) ATR-FT-IR spectra of seaweed extract samples and polysaccharide standards: (A) Cystoceira osmundacea, (B) Silvetia compressa, (C) Pterygophora californica, (D) Egregia menziessi, (E) Ecklonia arborea, (F) sodium alginate, (G) laminarin, and (H) fucoidan. Numbers 1 to 7 in FTIR spectra indicate most characteristic bands. (b) ATR-FT-IR spectrum of experimental seaweed extracts, sodium alginate, laminarin, and fucoidan standards: C. osmundacea seaweed extract (black line); S. compressa seaweed extract (green line); P. californica seaweed extract (red line); E. menziesii seaweed extract (royal blue line); E. arborea seaweed extract (aqua line); sodium alginate standard (purple line); laminarin standard (yellow line); fucoidan standard (navy line).

Phlorotannins identified in the present study have been previously reported in other brown seaweeds [14, 20-22].

Among the identified phlorotannins in the extracts, only a negative linear correlation was found between phloretol and DPPH $\left(R^{2}=0.69\right)$ and a positive linear correlation was found between three-PGU units of phlorotannin content and ORAC $\left(R^{2}=0.62\right)$, reinforcing the fact that NFE was also responsible of antioxidant activity. $\alpha$-Amylase $\mathrm{IC}_{10}$ did not show any correlation with phlorotannins. In contrast, $\alpha$-glucosidase $\mathrm{IC}_{10}$ showed strong negative linear correlation with the sum of phlorotannins $\left(R^{2}=0.78\right)$, with fucophloretol $\left(R^{2}=0.73\right)$ and a very high correlation with threePGU phlorotannin $\left(R^{2}=0.98\right)$ contents, but this happened only when E. menziessi data were not considered in the regressions. E. menziesii extract stands out from other seaweed extracts because of its very low phenolic content but relatively strong antioxidant activity, higher than expected, suggesting that other compounds were also responsible for these actions. A distinct inverse correlation between phenolic contents of $A$. nodosum and $\mathrm{IC}_{70}$ for $\alpha$-glucosidase inhibition was also observed by Apostolidis and Lee [70].

Dieckol, 8,8'-bieckol, phlorofucofuroeckol, fucophloroethol, and phlorotannins with low PGU are the main phlorotannins reported as antioxidants and potent $\alpha$-amylase and $\alpha$-glucosidase inhibitors [24, 25, 29]. Fucofuroeckol A and dioxinodehydroeckol have been previously reported as potent carbohydrase inhibitors for Eisenia bicyclis [18]. Phloroglucinol was described by Moon et al. [69] as inhibiting 50\% $\alpha$-glucosidase at $0.017 \mathrm{mg} \mathrm{mL}^{-1}$, and Andrade et al. [72] also related the presence of phloroglucinol $\left(0.23 \mathrm{mg}\right.$ dry algae $\left.\mathrm{mL}^{-1}\right)$ in $C$. tamariscifolia with the inhibition of glucosidase. In this study, the samples with the highest content of three-PGU pholorotannin, S. compressa and E. arborea, were the best inhibitors of this enzyme (Table 4).

$S$. compressa extract, the strongest $\alpha$-glucosidase inhibitor in this study, had the highest concentration of phlorotannins, fucophloroetol, and two- and three-PGU phlorotannins.

3.6. Sulfated Polysaccharides Identification. Infrared absorption frequencies corresponding to functional groups of different seaweed extracts are presented in Table 5. Sodium alginate, laminarin, and fucoidan standards were compared with the spectra of different seaweed extracts in the region between 3700 and $650 \mathrm{~cm}^{-1}$ (Figures 4(a) and 4(b)). Particularly, in our E. menziesii sample, no carbonyl group stretching frequency $\left(1616-1732 \mathrm{~cm}^{-1}\right)$ was observed as in the rest of the samples and standards, since this extract had the lowest polysaccharide content. Additionally, E. menziesii spectra did not show the characteristic signal around $3400 \mathrm{~cm}^{-1}$ corresponding to sulfated polysaccharides. Asymmetrical bending vibration (1404-1417 $\mathrm{cm}^{-1}$ ) of $\mathrm{CH}_{3}$ and $\mathrm{O}-\mathrm{H}$ was not observed in $S$. compressa and C. osmundacea extracts. A stretching vibration of sulfoxides $(\mathrm{S}=\mathrm{O})$ and $\mathrm{CN}$ stretching $\left(1028-1083.6 \mathrm{~cm}^{-1}\right)$ and sulfate groups at the axial $\mathrm{C} 4$ position and $\mathrm{C}-\mathrm{O}-\mathrm{S}$ symmetrical stretching vibrations (824.84-893.38 $\mathrm{cm}^{-1}$ ) were present among seaweed samples: E. menziesii, S. compressa, and E. arborea showed the strongest peaks. Results observed are in agreement with previous studies [73-79]. S. compressa showed stronger signals at the frequencies related to sulfate and carbonyl groups compared to E. arborea. FTIR of seaweed extracts showed the characteristic signals of 
sulfated polysaccharides with different chemical characteristics; therefore, the polysaccharides in combination with phlorotannins in the extracts seem responsible for the antioxidant and enzyme inhibitory effects $[34,80]$.

\section{Conclusion}

This study demonstrates the nutraceutical potential of brown seaweed species from Baja California. S. compressa and $E$. arborea present the highest activities to protect against oxidation, as well as to inhibit enzymes involved in intestinal carbohydrate digestion and assimilation. Their lower inhibitory effect against $\alpha$-amylase activity and stronger inhibition activity against $\alpha$-glucosidase is ideal for managing hyperglycemia with minimal side effects. The correlations between in vitro biological activities and extracts' chemical composition suggest that the bioactivities of $S$. compressa and E. arborea extracts could be attributed to their high content of polyphenols, phlorotannins (in particular, three-PGU phlorotannin), and associated polysaccharides (fucoidan, laminarin, and alginate). These seaweeds are potential candidates for food products and nutraceutical and pharmaceutical preparations and additives for diabetes management. Moreover, as S. compressa and E. arborea are edible species, their consumption should be encouraged.

\section{Future Perspectives}

In the future, studies on the optimization of $S$. compressa and E. arborea extraction conditions to maximize yields of the active compounds and on the properties of polysaccharides useful for the antioxidant activity and antidiabetic benefits are required. Furthermore, the evaluation of these seaweeds and their extracts as antidiabetic agents both at preclinical and clinical levels is imperative for material application in functional food and pharmaceutical industries.

\section{Data Availability}

The data (analytical results spreadsheets) used to support the findings of this study are available from the corresponding author upon request.

\section{Conflicts of Interest}

The authors declare that there are no conflicts of interest.

\section{Authors' Contributions}

ARMG and MTS contributed equally to this work. ARMG, MTS, and MMM participated in the execution of the experiments, as well as in the data analysis and the manuscript redaction. JRM participated in enzyme inhibition analysis. MMM and LSZ participated in ORAC analysis, LSZ, MMM, and JAGU contributed to HPLC-MS analysis and characterization. BABD participated in FTIR analysis and characterization. LECS and DRM contributed to writing draft and review and editing. LECS and JAGU conceived and designed the experiments and contributed in supervision and project administration. All authors read and approved the final manuscript.

\section{Acknowledgments}

This work was supported by the Mexican National Council of Science and Technology (CONACYT, Research Project 238458, Ciencia Basica 2014). The authors acknowledge the infrastructure support from the Universidad Autónoma de Nuevo León (Programa Maricultura) and the Tecnológico de Monterrey (NutriOmics Research Group).

\section{References}

[1] J. E. Shaw, R. A. Sicree, and P. Z. Zimmet, "Global estimates of the prevalence of diabetes for 2010 and 2030," Diabetes Research and Clinical Practice, vol. 87, no. 1, pp. 4-14, 2010.

[2] R. Testa, A. R. Bonfigli, F. Prattichizzo, L. La Sala, V. De Nigris, and A. Ceriello, "The "metabolic memory" theory and the early treatment of hyperglycemia in prevention of diabetic complications," Nutrients, vol. 9, no. 5, p. 437, 2017.

[3] X. Shan, X. Liu, J. Hao et al., "In vitro and in vivo hypoglycemic effects of brown algal fucoidans," International Journal of Biological Macromolecules, vol. 82, pp. 249-255, 2016.

[4] A. Brabakaran and N. Thangaraju, "In vitro evaluation of methanolic extract of red seaweeds against $\alpha$-amylase and $\alpha$-glucosidase enzyme inhibitory activity," Asian Journal of Pharmacy and Pharmacology, vol. 4, no. 3, pp. 339-342, 2018.

[5] A. A. Hamza, T. S. Ksiksi, and O. A. A. Shamsi, " $\alpha$-glucosidase inhibitory activity of common traditional medicinal plants used for diabetes mellitus," Journal of Developing Drugs, vol. 4, no. 5, pp. 1-5, 2015.

[6] S. R. Joshi, E. Standl, N. Tong, P. Shah, S. Kalra, and R. Rathod, "Therapeutic potential of $\alpha$-glucosidase inhibitors in type 2 diabetes mellitus: an evidence-based review," Expert Opinion on Pharmacotherapy, vol. 16, no. 13, pp. 1959-1981, 2015.

[7] R. Vinayagam, J. Xiao, and B. Xu, "An insight into anti-diabetic properties of dietary phytochemicals," Phytochemistry Reviews, vol. 16, no. 3, pp. 535-553, 2017.

[8] M. Murray, A. L. Dordevic, L. Ryan, L. Ryan, and M. P. Bonham, "Phlorotannins and macroalgal polyphenols: potential as functional food ingredients and role in health promotion," in Functional Food and Human Health, V. Rani and U. C. S. Yadav, Eds., Springer Nature Singapore Pte Ltd., Singapore, 2018.

[9] M. A. Sheliya, R. Begum, K. K. Pillai et al., "In vitro $\alpha$-glucosidase and $\alpha$-amylase inhibition by aqueous, hydroalcoholic, and alcoholic extract of minuscule Ephorbia hirta L.," Drug Development and Therapeutics, vol. 7, no. 1, pp. 26-30, 2016.

[10] S. L. Holdt and S. Kraan, "Bioactive compounds in seaweed: functional food applications and legislation," Journal of Applied Phycology, vol. 23, no. 3, pp. 543-597, 2011.

[11] K. Collins, G. Fitzgerald, C. Stanton, and R. Ross, "Looking beyond the terrestrial: the potential of seaweed derived bioactives to treat non-communicable diseases," Marine Drugs, vol. 14, no. 3, p. 60, 2016. 
[12] G. Swarnalatha, "Comparison of nutritive value of seaweed with other terrestrial foods-a review," International Journal of Food Sciences and Nutrition, vol. 7, pp. 2320-7876, 2018.

[13] P. Cherry, C. O'Hara, P. J. Magee, E. M. Mcsorley, and P. J. Allsopp, "Risks and benefits of consuming edible seaweeds," Nutrition Reviews, vol. 77, no. 5, pp. 307-329, 2019.

[14] U. Etxeberria, A. L. de la Garza, J. Campión, J. A. Martínez, and F. I. Milagro, "Antidiabetic effects of natural plant extracts via inhibition of carbohydrate hydrolysis enzymes with emphasis on pancreatic alpha amylase," Expert Opinion on Therapeutic Targets, vol. 16, no. 3, pp. 269-297, 2012.

[15] E. M. Balboa, E. Conde, A. Moure, E. Falqué, and H. Domínguez, "In vitro antioxidant properties of crude extracts and compounds from brown algae," Food Chemistry, vol. 138, no. 2-3, pp. 1764-1785, 2013.

[16] P. A. Tenorio-Rodriguez, J. I. Murillo-Álvarez, Á. I. CampaCordova, and C. Angulo, "Antioxidant screening and phenolic content of ethanol extracts of selected Baja California Peninsula macroalgae," Journal of Food Science and Technology, vol. 54, no. 2, pp. 422-429, 2017.

[17] Y. X. Chin, P. E. Lim, C. A. Maggs, S. M. Phang, Y. Sharifuddin, and B. D. Green, "Anti-diabetic potential of selected Malaysian seaweeds," Journal of Applied Phycology, vol. 27, no. 5, pp. 2137-2148, 2015.

[18] S.-H. Eom, S.-H. Lee, N.-Y. Yoon et al., " $\alpha$-Glucosidase- and $\alpha$-amylase-inhibitory activities of phlorotannins from Eisenia bicyclis," Journal of the Science of Food and Agriculture, vol. 92, no. 10, pp. 2084-2090, 2012.

[19] S. Lordan, T. J. Smyth, A. Soler-Vila, C. Stanton, and R. P. Ross, "The $\alpha$-amylase and $\alpha$-glucosidase inhibitory effects of Irish seaweed extracts," Food Chemistry, vol. 141, no. 3, pp. 2170-2176, 2013.

[20] A. J. Steevensz, S. L. MacKinnon, R. Hankinson et al., "Profiling phlorotannins in brown macroalgae by liquid chromatography-high resolution mass spectrometry," Phytochemical Analysis, vol. 23, no. 5, pp. 547-553, 2012.

[21] J. H. Isaza Martínez and H. G. Torres Castañeda, "Preparation and chromatographic analysis of phlorotannins," Journal of Chromatographic Science, vol. 51, no. 8, pp. 825-838, 2013.

[22] M. S. Tierney, A. Soler-Vila, D. K. Rai, A. K. Croft, N. P. Brunton, and T. J. Smyth, "UPLC-MS profiling of low molecular weight phlorotannin polymers in Ascophyllum nodosum, Pelvetia canaliculata and Fucus spiralis," Metabolomics, vol. 10, no. 3, pp. 524-535, 2014.

[23] S. Mezghani, D. Csupor, I. Bourguiba et al., "Characterization of phenolic compounds of Ulva rigida (Chlorophycae) and its antioxidant activity," European Journal of Medicine Plants, vol. 12, no. 1, pp. 1-9, 2016.

[24] B. Liu, K. T. Kongstad, S. Wiese, A. K. Jäger, and D. Staerk, "Edible seaweed as future functional food: identification of $\alpha$-glucosidase inhibitors by combined use of high-resolution $\alpha$-glucosidase inhibition profiling and HPLC-HRMS-SPENMR," Food Chemistry, vol. 203, pp. 16-22, 2016.

[25] Y.-X. Li, I. Wijesekara, Y. Li, and S.-K. Kim, "Phlorotannins as bioactive agents from brown algae," Process Biochemistry, vol. 46, no. 12, pp. 2219-2224, 2011.

[26] M. Murray, A. L. Ryan, and M. P. Bonham, "An emerging trend in functional food for the prevention of cardiovascular disease and diabetes: marine algal polyphenols," Critical Reviews in Food Science and Nutrition, vol. 58, no. 8, pp. 1342-1358, 2018.
[27] C. Zhao, C. Yang, B. Liu et al., "Bioactive compounds from marine macroalgae and their hypoglycemic benefits," Trends in Food Science \& Technology, vol. 72, pp. 1-12, 2018.

[28] C. Jacobsen, A.-D. M. Sørensen, S. L. Holdt, C. C. Akoh, and D. B. Hermund, "Source, extraction, characterization, and applications of novel antioxidants from seaweed," Annual Review of Food Science and Technology, vol. 10, no. 1, pp. 541-568, 2019.

[29] J. Kellogg, M. Grace, and M. Lila, "Phlorotannins from Alaskan seaweed inhibit carbolytic enzyme activity," Marine Drugs, vol. 12, no. 10, pp. 5277-5294, 2014.

[30] A. C. Murugan, M. R. Karim, M. B. M. Yusoff, S. H. Tan, M. F. B. F. Asras, and S. S. Rashid, "New insights into seaweed polyphenols on glucose homeostasis," Pharmaceutical Biology, vol. 53, no. 8, pp. 1087-1097, 2015.

[31] T. S. Vo, H. N. Dai, and K. Se-kwon, "Brown algal polyphenol and its pharmaceutical properties," in Marine-Derived Biomaterials for Tissue Engineering Applications, A. H. Choiand and B. Ben-Nissan, Eds., vol. 14Springer Singapore, Singapore, pp. 223-243, 2019.

[32] K.-T. Kim, L.-E. Rioux, and S. L. Turgeon, "Alpha-amylase and alpha-glucosidase inhibition is differentially modulated by fucoidan obtained from Fucus vesiculosus and Ascophyllum nodosum," Phytochemistry, vol. 98, pp. 27-33, 2014.

[33] S. Lakshmanasenthil, T. Vinothkumar, D. Geetharamani, T. Marudhupandi, G. Suja, and N. S. Sindhu, "Fucoidan-a novel $\alpha$-amylase inhibitor from Turbinaria ornata with relevance to NIDDM therapy," Biocatalysis and Agricultural Biotechnology, vol. 3, no. 3, pp. 66-70, 2014.

[34] J. Wang, S. Hu, S. Nie, Q. Yu, and X. Mingyong, "Reviews on mechanisms of in vitro antioxidant activity of polysaccharides," Oxidative Medicine and Cellular Longevity, vol. 2016, Article ID 5692852, 13 pages, 2016.

[35] K. H. S. Farvin and C. Jacobsen, "Phenolic compounds and antioxidant activities of selected species of seaweeds from Danish Coast," Food Chemistry, vol. 138, no. 2-3, pp. 16701681, 2013.

[36] T. Wang, R. Jónsdóttir, and G. Ólafsdóttir, "Total phenolic compounds, radical scavenging and metal chelation of extracts from Icelandic seaweeds," Food Chemistry, vol. 116, no. 1, pp. 240-248, 2009.

[37] D. B. Hermund, Extraction, characterization and application of antioxidants from the Nordic brown alga Fucus vesiculosus, $\mathrm{PhD}$ thesis, National Institute of Food and Agriculture, Technical University Denmark, Lyngby, Denmark, 2016.

[38] Y. Li, Z. J. Qian, B. Ryu, S. H. Lee, M. M. Kim, and S. K. Kim, "Chemical components and its antioxidant properties in vitro: an edible marine brown alga, Ecklonia cava," Bioorganic \& Medicinal Chemistry, vol. 17, no. 5, pp. 1963-1973, 2009.

[39] T. Hu, D. Liu, Y. Chen, J. Wu, and S. Wang, "Antioxidant activity of sulfated polysaccharide fractions extracted from Undaria pinnitafida in vitro," International Journal of Biological Macromolecules, vol. 46, no. 2, pp. 193-198, 2010.

[40] P. Rupérez, O. Ahrazem, and J. A. Leal, "Potential antioxidant capacity of sulfated polysaccharides from the edible marine brown seaweed Fucus vesiculosus," Journal of Agricultural and Food Chemistry, vol. 50, no. 4, pp. 840-845, 2002.

[41] J. Wang, Q. Zhang, Z. Zhang, and Z. Li, “Antioxidant activity of sulfated polysaccharide fractions extracted from Laminaria japonica," International Journal of Biological Macromolecules, vol. 42, no. 2, pp. 127-132, 2008.

[42] J. A. Zertuche-González, "Aprovechamiento de las algas marinas en Mexico; estado actual y retos futuros," in 
Proceedings of the VII Congreso Nacional de Ficologia (UNAM Iztacala), vol. 1, pp. 101-110, Mexico, October 2013.

[43] D. Robledo, "The seaweed resources of Mexico," in Seaweed Resources of the World, A. T. Critchley and M. Ohno, Eds., pp. 331-342, Japan International Cooperation Agency, Tokyo, Japan, 1998.

[44] D. L. Arvizu, Y. E. Rodriguez, G. Hernandez, and J. I. Murillo, "Chemical constituents of Eisenia arborea (areschoug) from Baja California sur, Mexico," Investigaciones Marinas Valparaiso, vol. 35, no. 2, pp. 63-69, 2007.

[45] C. Landa-Cansigno, G. Hernández-Carmona, D. L. ArvizuHiguera, M. Muñoz-Ochoa, and C. J. Hernández-Guerrero, "Bimonthly variation in the chemical composition and biological activity of the brown seaweed Eisenia arborea (laminariales: ochrophyta) from Bahia Magdalena, Baja California sur, Mexico," Journal of Applied Phycology, vol. 29, no. 5, pp. 2605-2615, 2017.

[46] M. Tapia-Salazar, I. G. Arévalo-Rivera, M. Maldonado-Muñiz et al., "The dietary fiber profile, total polyphenol content, functionality of Silvetia compressa and Ecklonia arborea, and modifications induced by high hydrostatic pressure treatments," Food and Bioprocess Technology, vol. 12, no. 3, pp. 512-523, 2019.

[47] G. Guerra-Rivas, C. M. Gómez-Gutiérrez, G. AlarcónArteaga, I. E. Soria-Mercado, and N. E. Ayala-Sánchez, "Screening for anticoagulant activity in marine algae from the Northwest Mexican Pacific coast," Journal of Applied Phycology, vol. 23, no. 3, pp. 495-503, 2011.

[48] E. Hernández-Garibay, J. A. Zertuche-González, and I. Pacheco-Ruiz, "Sulfated Polysaccharides (Fucoidan) from the brown seaweed silvetia compressa (J. Agardh) E. Serrão, T. O. Cho, S. M. Boo \& brawley," Journal of Applied Phycology, 2019.

[49] P. Gabrielson, T. Widdowson, S. Lindstrom, M. Hawkes, and R. Scagel, Keys to the Benthic Marine Algae and Seagrasses of British Columbia, Southeast Alaska, Washington and Oregon, Phycological Contribution Number 5, Department of Botany, University of British Columbia, Vancouver, Canada, 2000.

[50] AOAC, Official Methods of Analysis of the Association of Official Analytical Chemists, AOAC, Washington, DC, USA, 16th edition, 1999.

[51] Y. Li, F. G. Naghdi, S. Garg et al., "A comparative study: the impact of different lipid extraction methods on current microalgal lipid research," Microbial Cell Factories, vol. 13, no. 1, p. 14, 2014.

[52] J. Xi, D. Shen, S. Zhao, B. Lu, Y. Li, and R. Zhang, "Characterization of polyphenols from green tea leaves using a high hydrostatic pressure extraction," International Journal of Pharmaceutics, vol. 382, no. 1-2, pp. 139-143, 2009.

[53] A. Cabello-Pasini, V. Macías-Carranza, R. Abdala, N. Korbee, and F. L. Figueroa, "Effect of nitrate concentration and UVR on photosynthesis, respiration, nitrate reductase activity, and phenolic compounds in Ulva rigida (Chlorophyta)," Journal of Applied Phycology, vol. 23, no. 3, pp. 363-369, 2011.

[54] M. Tako, S. Tohma, T. Taira, and M. Ishihara, "Gelation mechanism of deacetylated rhamsan gum," Carbohydrate Polymers, vol. 54, no. 3, pp. 279-285, 2003.

[55] L. García-Becerra, S. J. Verde, R. R. Castro et al., "Biological activity of mexican grape pomace extract," Revista Mexicana de Ciencias Farmacéuticas, vol. 41, pp. 28-36, 2010.

[56] B. Ou, M. Hampsch-Woodill, and R. L. Prior, "Development and validation of an improved oxygen radical absorbance capacity assay using fluorescein as the fluorescent probe,"
Journal of Agricultural and Food Chemistry, vol. 49, no. 10, pp. 4619-4626, 2001.

[57] M. I. Kazeem, J. O. Adamson, and I. A. Ogunwande, "Modes of inhibition of $\alpha$-amylase and $\alpha$-glucosidase by aqueous extract of Morinda lucida benth leaf," BioMed Research International, vol. 2013, Article ID 527570, 6 pages, 2013.

[58] G. L. Miller, "Use of dinitrosalicylic acid reagent for determination of reducing sugar," Analytical Chemistry, vol. 31, no. 3, pp. 426-428, 1959.

[59] B. Mayur, S. Sandesh, S. Shruti, and S. Sung-Yum, "Antioxidant and $\alpha$-glucosidase inhibitory properties of Carpesium abrotanoides," Journal of Medical Plants Research, vol. 4, no. 15, pp. 1547-1553, 2010.

[60] P. Burtin, "Nutritional value of seaweeds," Electronic Journal of Environmental, Agricultural and Food Chemistry, vol. 2, pp. 498-510, 2003.

[61] L.-E. Rioux, S. L. Turgeon, and M. Beaulieu, "Characterization of polysaccharides extracted from brown seaweeds," Carbohydrate Polymers, vol. 69, no. 3, pp. 530-537, 2007.

[62] M. Noda, T. Ogami, H. Ohara, N. Murase, I. Ikeda, and Y. Tanoue, "Effects of polyphenol content and thallus toughness of five species of Kelp (Laminariales, Lessoniaceae) on the feeding preference of the Japanese temperate rabbitfish Siganus fuscescens," Aquaculture Science, vol. 61, pp. 113-117, 2013.

[63] K. L. Van Alstyne, J. J. McCarthy III, C. L. Hustead, and D. O. Duggins, "Geographic variation in polyphenolic levels of Northeastern Pacific kelps and rockweeds," Marine Biology, vol. 133, no. 2, pp. 371-379, 1999.

[64] T. I. Imbs, N. P. Krasovskaya, S. P. Ermakova, T. N. Makarieva, N. M. Shevchenko, and T. N. Zvyagintseva, "Comparative study of chemical composition and antitumor activity of aqueous-ethanol extracts of brown algae Laminaria cichorioides, Costaria costata, and Fucus evanescens," Russian Journal of Marine Biology, vol. 35, no. 2, pp. 164-170, 2009.

[65] O.-H. Lee, K.-Y. Yoon, K.-J. Kim, S. You, and B.-Y. Lee, "Seaweed extracts as a potential tool for the attenuation of oxidative damage in obesity-related pathologies," Journal of Phycology, vol. 47, no. 3, pp. 548-556, 2011.

[66] M. Plaza, M. Amigo-Benavent, M. D. del Castillo, E. Ibáñez, and M. Herrero, "Facts about the formation of new antioxidants in natural samples after subcritical water extraction," Food Research International, vol. 43, no. 10, pp. 2341-2348, 2010.

[67] P. Wan, X. Yang, B. Cai et al., "Ultrasonic extraction of polysaccharides from Laminaria japonica and their antioxidative and glycosidase inhibitory activities," Journal of Ocean University of China, vol. 14, no. 4, pp. 651-662, 2015.

[68] K. M. Shaich, X. Tian, and J. Xie, "Reprint of "hurdles and pirfalls in measuring antioxidant efficacy: a critical evaluation of ABTS, DPPH, and ORAC assays"," Journal of Functional Foods, vol. 18, pp. 782-796, 2015.

[69] H. E. Moon, M. N. Islam, B. R. Ahn et al., "Protein tyrosine phosphatase $1 \mathrm{~B}$ and $\alpha$-glucosidase inhibitory phlorotannins from edible brown algae, Ecklonia stolonifera and Eisenia bicyclis," Bioscience, Biotechnology, and Biochemistry, vol. 75, no. 8, pp. 1472-1480, 2011.

[70] E. Apostolidis and C. M. Lee, "In vitro potential of ascophyllum nodosum phenolic antioxidant-mediated $\alpha$-glucosidase and $\alpha$-amylase inhibition," Journal of Food Science, vol. 75, no. 3, pp. H97-H102, 2010.

[71] T. Shibata, K. Ishimaru, S. Kawaguchi, H. Yoshikawa, and Y. Hama, "Antioxidant activities of phlorotannins isolated 
from Japanese Laminariaceae," Journal of Applied Phycology, vol. 20, no. 5, pp. 705-711, 2008.

[72] P. B. Andrade, M. Barbosa, R. P. Matos et al., "Valuable compounds in macroalgae extracts," Food Chemistry, vol. 138, no. 2-3, pp. 1819-1828, 2013.

[73] S. J. Lim, W. M. Wan Aida, M. Y. Maskat, S. Mamot, J. Ropien, and D. Mazita Mohd, "Isolation and antioxidant capacity of fucoidan from selected Malaysian seaweeds," Food Hydrocolloids, vol. 42, pp. 280-288, 2014.

[74] D. Park, Y.-S. Yun, and J. M. Park, "Studies on hexavalent chromium biosorption by chemically-treated biomass of Ecklonia sp," Chemosphere, vol. 60, no. 10, pp. 1356-1364, 2005.

[75] N. Yee, L. G. Benning, V. R. Phoenix, and F. G. Ferris, "Characterization of metal-Cyanobacteria sorption reactions: a combined macroscopic and infrared spectroscopic investigation," Environmental Science \& Technology, vol. 38, no. 3, pp. 775-782, 2004.

[76] S. Kannan, "FT-IR and EDS analysis of the seaweeds Sargassum wightii (brown algae) and Gracilaria corticata (red algae)," International Journal of Current Microbiology and Applied Sciences, vol. 3, pp. 341-351, 2014.

[77] S. H. S. Shekhar, G. Lyons, C. McRoberts et al., "Brown seaweed species from Strangford Lough: compositional analyses of seaweed species and biostimulant formulations by rapid instrumental methods," Journal of Applied Phycology, vol. 24, no. 5, pp. 1141-1157, 2011.

[78] J. Guo and X. Zhang, "Metal-ion interactions with sugars: the crystal structure and FTIR study of an $\mathrm{SrCl}_{2}$-fructose complex," Carbohydrate Research, vol. 339, no. 8, pp. 1421-1426, 2004.

[79] L. D'Souza, P. Devi, and M. P. Divya Shridhar, "Use of fourier transform infrared (FTIR) spectroscopy to study cadmiuminduced changes in Padina tetrastromatica (hauck)," Analytical Chemistry Insights, vol. 3, pp. 135-143, 2008.

[80] D. S. Ceri Austi, J. William Allwood, and G. J. McDougall, "Extracts from the edible seaweed, Ascophyllum nodosum, inhibit lipase activity in vitro: contributions of phenolic and polysaccharide components," Food \& Function, vol. 9, no. 1, pp. 502-510, 2018. 


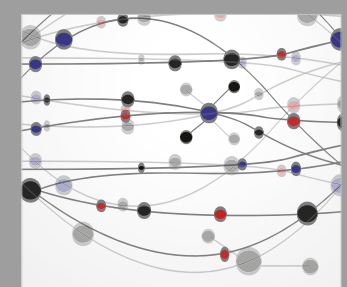

The Scientific World Journal
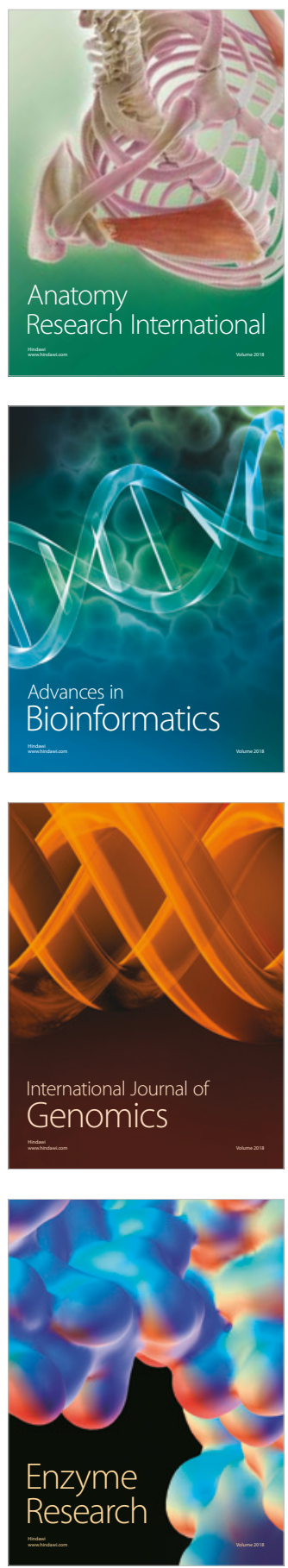
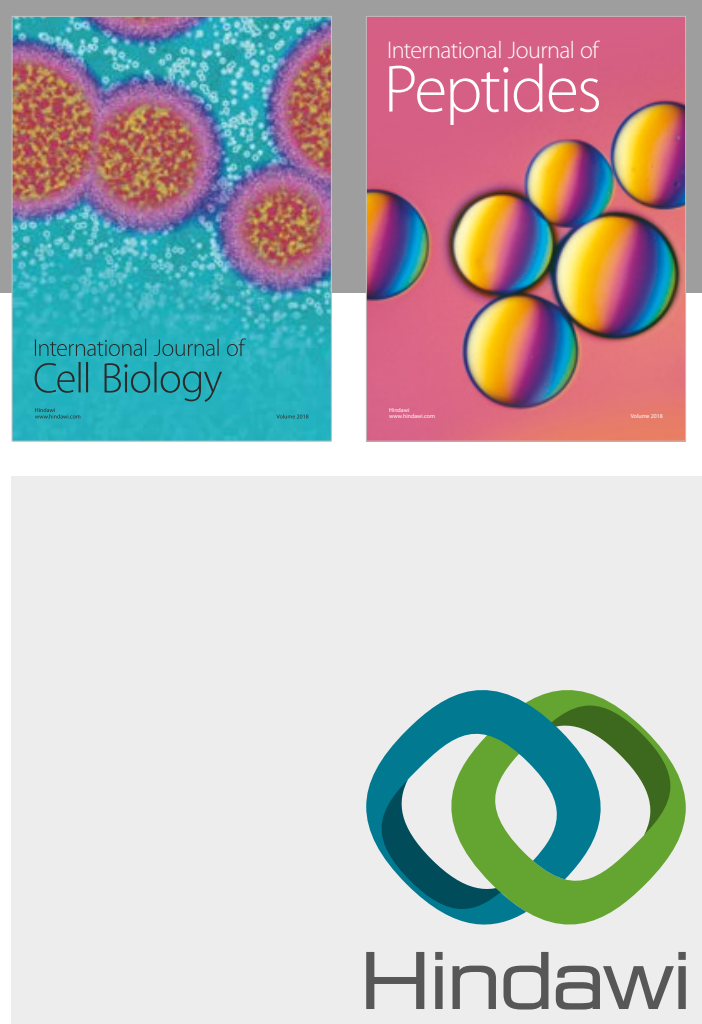

Submit your manuscripts at

www.hindawi.com
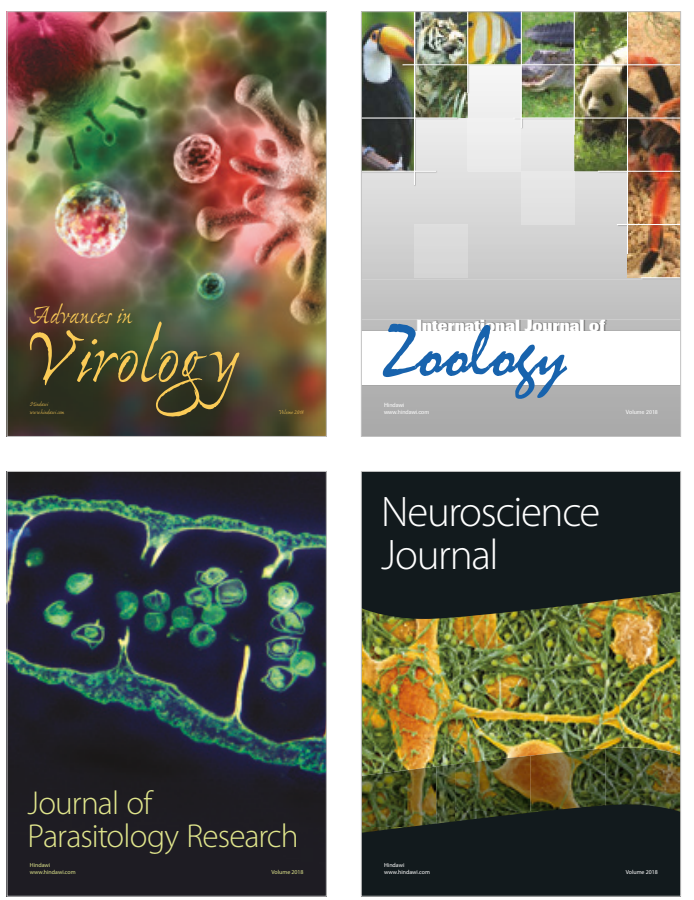
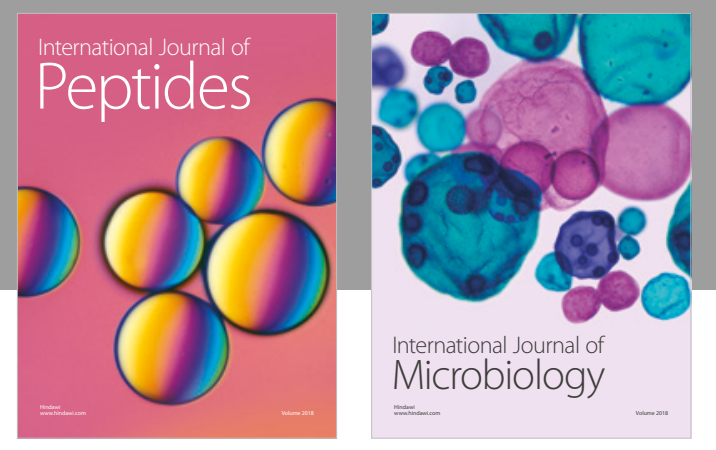

nternational Journal of Microbiology
Journal of
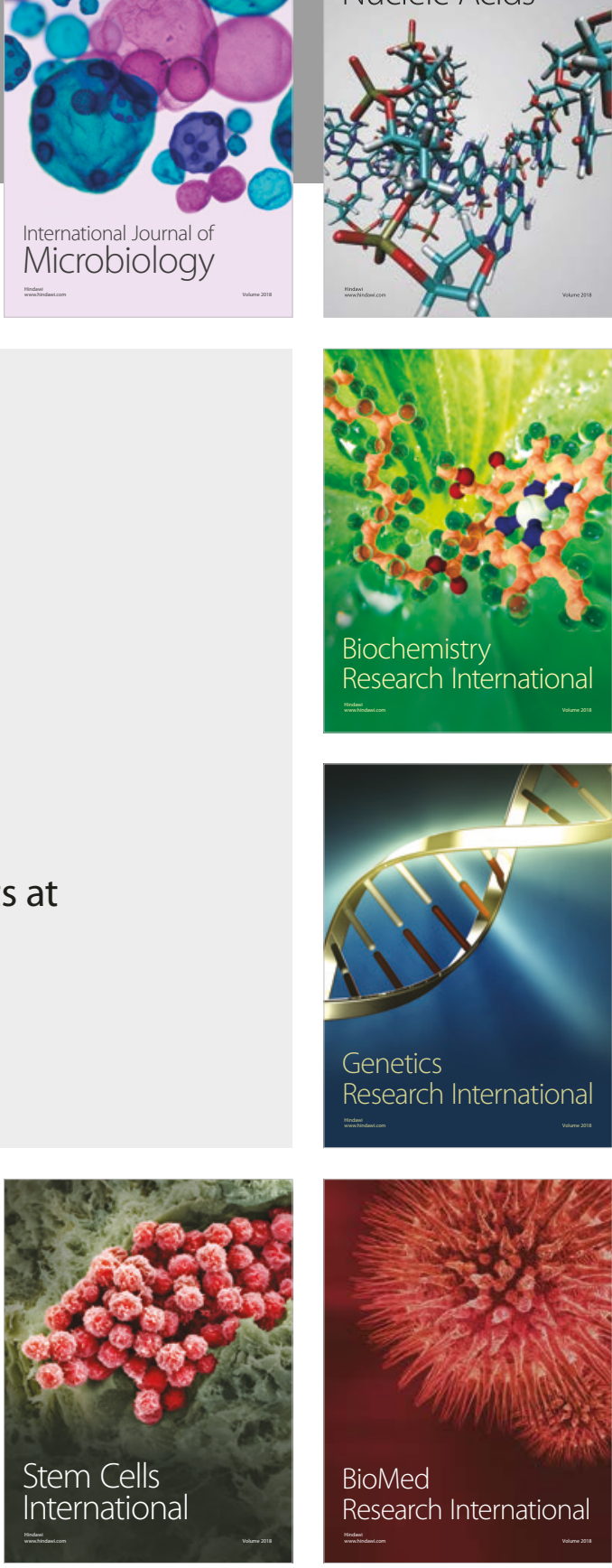
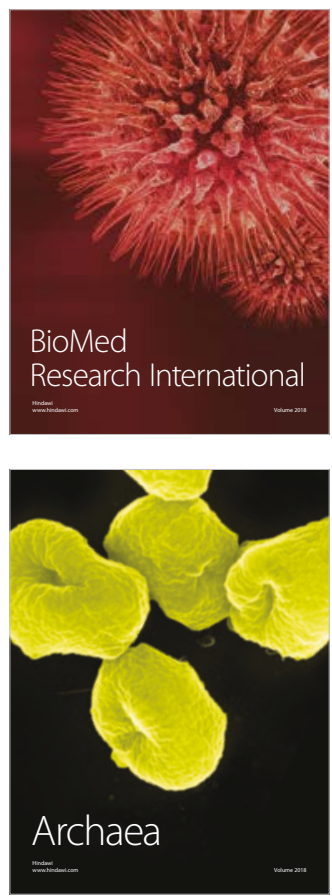